\title{
CREDENTIAL RECOGNITION OF INTERNATIONALLY TRAINED DENTISTS IN CANADA
}

\section{BY}

Anahita Tohidi, BA York University, 2002

\author{
A Major Research Paper \\ presented to Ryerson University \\ in partial fulfillment of the requirements for the degree of \\ Master of Arts \\ in the Program of \\ Immigration and Settlement Studies
}

Toronto, Ontario, Canada, 2014

(C) Anahita Tohidi 


\section{AUTHOR'S DECLARATION FOR ELECTRONIC SUBMISSION OF A MAJOR RESEARCH PAPER (MRP)}

I hereby declare that I am the sole author of this Major Research Paper. This is a true copy of the MRP, including any required final revisions, as accepted by my examiners.

I authorize Ryerson University to lend this MRP to other institutions or individuals for the purpose of scholarly research

I further authorize Ryerson University to reproduce this MRP by photocopying or by other means, in total or in part, at the request of other institutions or individuals for the purpose of scholarly research.

I understand that my MRP may be made electronically available to the public.

Anahita Tohidi 


\title{
Credential Recognition of Internationally Trained Dentists in Canada \\ Anahita Tohidi \\ Master of Arts 2014 \\ Immigration and Settlement Studies \\ Ryerson University
}

\begin{abstract}
This paper highlights the changes in the Canadian immigration policies, mainly the point system and the credential recognition of internationally trained professionals in Canada. Focusing on the challenges and barriers they face, the paper examines the role of the government and the regulatory bodies in the foreign credential recognition process. The paper primarily focuses on the licensing process of internationally trained dentists in Canada. Using a survey questionnaire, the study analyses the experience of 52 internationally trained dentists in the GTA who are seeking licensing and the challenges they face in the process.
\end{abstract}

Key words: Internationally Trained Dentists; Credential Recognition, Point System, Internationally Trained Professionals; Points System 


\section{ACKNOWLEDGMENTS}

I wish to express my most sincere gratitude to my supervisor Dr. Arthur Ross for his continued support, guidance and most of all patience. I would like to also thank my second reader Dr. Myer Siemiatycki for his guidance throughout the program.

I wish to express my sincere thanks to my dear friends, Emma Flynn for editing my paper, to Kwan Ho Leung for patiently answering all my questions and my professors and classmates who inspired me and taught me so much.

I also want to thank my mom for encouraging me to go to graduate school, for watching my girls and supporting me throughout the program; my sister Sharareh for watching my baby when I needed to be in school; and my husband Babak who has been a great support and mentor in every step of the way.

This has been an amazing experience for me and I would not have been able to do it without their support and guidance. 


\section{DEDICATION}

For My Daughters, Lenna and Liara 
Table of Contents

Chapter 1

Introduction

\section{Chapter 2}

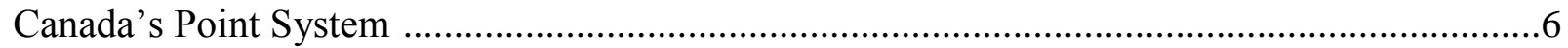

The Employment Outcomes of Professionals ......................................................................12

\section{Chapter 3}

Foreign Credential Recognition in Canada .................................................................... 15

The Employment Outcomes of Professionals ....................................................................17

\section{Chapter 4}

Licensing process of Internationally Trained Dentists in Canada.

\section{Chapter 5}

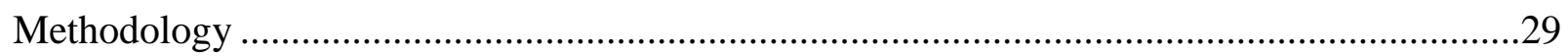

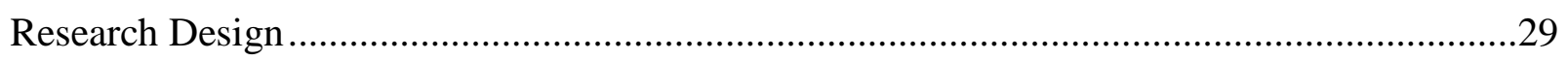

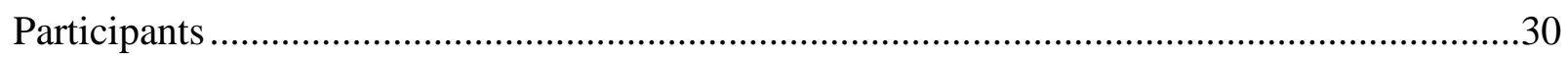

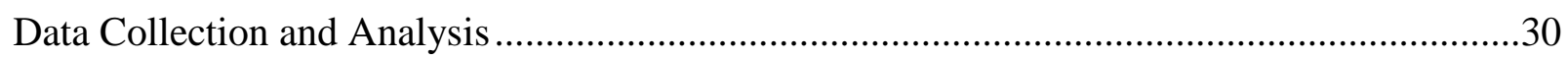

\section{Chapter 6}

Results

\section{Chapter 7}

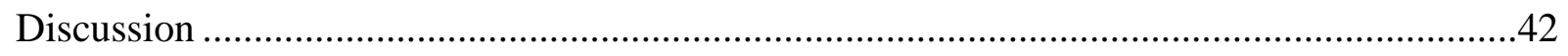

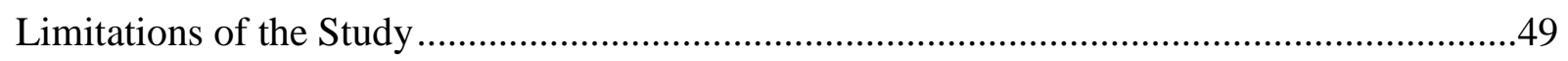

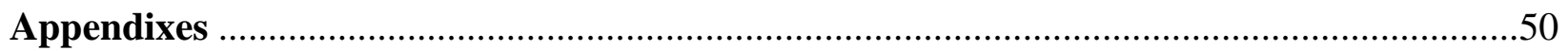

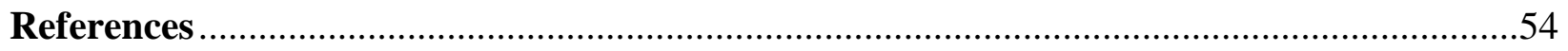




\section{List of Tables}

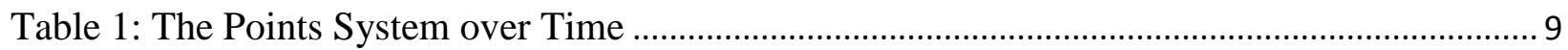

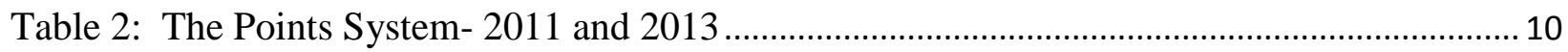

Table 3: Summary of Historical Pass Rates for the NDEB Equivalency Process ............................ 25

Table 4) Age and gender distribution of the participants.............................................................. 31

Table 5) Country of Origin and the Immigration Program.............................................................. 32

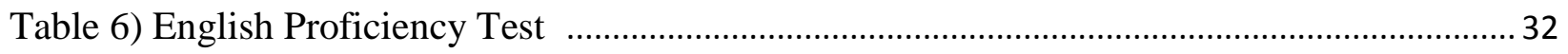

Table 7) Age Distribution of the Participants Who Passed the Assessment of Knowledge ............ 33

Table 8) Age Distribution of the Participant Who passed the Assessment of Clinical Judgment 33

Table 9) Age Distribution of the participants who passed the Assessment of Clinical Skills ....... 33

Table 10) Count of Dentists Who Attended Dental Training Classes and the Costs Associated

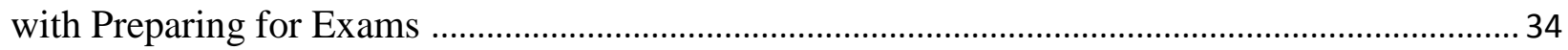

Table 11) Source of income to pay for living expenses ................................................................. 35

Table 12) Resources used to obtain information on dental licensing................................................ 36

Table 13) a. Difficulty obtaining information; b. Staff helpful when getting information;

c. Aware of dental licensing in Canada before arrival; d. Choice of immigrating to Canada with prior knowledge about licensing; e. Moving to another city for a faster licensing process. .......... 36

Table 14) Age comparison between participants accepted into the Qualifying Program and those not in the program. 


\section{List of Figures}

Chart 1) Number of years participants studied for exams

Chart 2) Age comparison between participants accepted into the Qualifying Program and those

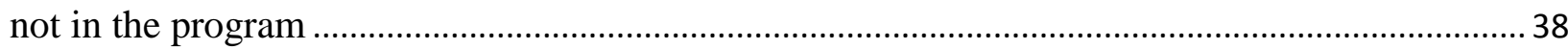

Chart 3) Percentage of participants who were aware of the licensing process in Canada prior to

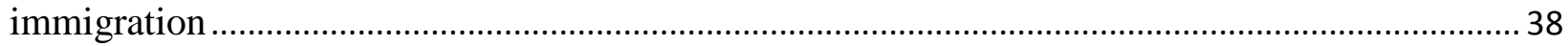

Chart 4) Percentage of participants who would have been willing to immigrate to Canada based

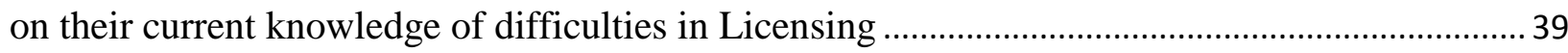




\section{Chapter 1}

\section{Introduction}

Canadian immigration policy has been used as a tool to boost the economy in recent years (Green, 2004). For Canada's knowledge-based global economy to be competitive internationally trained professionals are needed to fill labour market needs (Ikura, 2007). Thus, Canada's immigration policies and regulations as well as policy amendments are designed to recruit highly skilled immigrants. While changes to the Canadian Immigration policy implemented in the 1990s focused on bringing in immigrants with higher levels of human capital, the difficulties the immigrants faced in entering the labour market has prompted the government to make further changes to the Federal Skilled Worker Program (FSWP) (Ferrer, Picot \& Riddell, 2012).

Changes to Immigration and Refugee Protection Act (IRPA) in 2002 were driven by federal goals of improving the economic outcomes of immigrants arriving to Canada by increasing the points assigned to education, language ability and work experience. Some of the more recent changes since 2008 have continued to focus on the labour market outcomes of the immigrants. In 2008, occupation criteria were introduced restricting admission to applicants for the FSWP who were in 38 high-demand occupations such as health, skilled trades, finance and resource extraction (Citizenship and Immigration Canada, 2013). In 2010, mandatory language testing was introduced to the FSWP in the economic class and the government placed occupation caps on the number of applicants in each occupation (Alboim \& Cohl, 2012). In 2011, the government reduced the number of FSW applicants admitted to Canada further and introduced the PHD stream under FSWP (Alboim \& Cohl, 2012). 
In 2012, the applications received before 2008 and after July 2012 under the FSWP were returned due to the backlog in processing the applications (Alboim \& Cohl, 2012). These changes were a response to the negative labour market outcomes of the recent immigrants and increasing use of the Canadian Experience program to address labour market shortages in certain regions, and encourage settlement outside of the three largest cities. (Ferrer et al., 2012) Emphasising on credential recognition, Economic Action Plan (2012) announced "the Government's intention to support further improvements to foreign credential recognition and to work with provinces and territories to identify the next set of target occupations for inclusion, beyond 2012, under the Pan-Canadian Framework for the Assessment and Recognition of Foreign Qualifications.” (Assessment and Recognition of Foreign Qualifications)

Under the FSWP, Canadian immigration policy awards a large number of points to applicants with higher education. Immigrants applying through the FSWP are led to believe that they will have no difficulty finding employment when they arrive in Canada. In fact, because their education and skills are highly valued by the FSWP system of selection, they can assume that they will be successful in the labour market (Schwartz \& Dhillon- Penner, 2009). In order to achieve long-term economic prosperity and success, Canada needs to ensure the best talent, including those with foreign education, training, and experience, are retained and that their skills are fully utilized (Ikura, 2007). However, the labour market outcome of many immigrants admitted through the FSWP has been poor. The discrepancy between the formal qualifications of immigrants and their actual performance in the labour market has resulted in the de-skilling of immigrants (Reitz, 2005). Despite the fact that immigrants' skill levels have risen, their earnings have fallen in both relative and absolute terms (Reitz 2005). The economic success of 
immigrants in the labour market is an indicator of the success of Canadian immigration policy (Reitz, 2005).

Upon their arrival in Canada, many individuals who are selected under FSWP are not able to apply their education and skills from abroad, and instead can only find employment in occupations where they do not use their cognitive skills (Imai, Stacey \& Warman, 2011). These immigrants face challenges because their work experience or education is not recognized by professional regulatory bodies, have a lack of language proficiency and/or international difference in professional training (Sumption, 2013). As a result, they face difficulties when applying for jobs in Canada. It is also challenging for certain skilled trade workers to obtain Canadian credentials (Alboim, Finnie \& Meng, 2005). Internationally trained professionals applying for regulated professional licenses face additional challenges (Sumption 2013) because of restrictions and limited seats available in training programs for internationally trained immigrants. There has been much research conducted and recommendations given to ensure higher employment of skills for immigrants. For example, Alboim et al, (2005) state that the Canadian government needs to introduce programs that increase the returns on foreign education and reduce the discounting of immigrants skills. Alboim et al. (2005) argue that these potential programs will have a positive impact on immigrants, employers and the Canadian economy as a whole.

The underutilization of immigrants' skills is a major weakness of the Canadian FSWP. According to human capital theory, "workers' earnings reflect the productive value of their skills particularly based on formal education and work experience" (Reitz, 2005). This theory suggests "people spend on themselves in diverse ways, not for the sake of enjoyment, but for the sake of future pecuniary and non- pecuniary returns" (Blaug, 1976, p.829). For example, by investing in 
education, one expects future returns of having a good job (Blaug, 1976, p.829). The demand for upper secondary education has led individuals to seek higher education and forgo the costs of additional schooling in the hope of future earnings (Blaug, 1976, p.829). According to Benhabib and Spiegal (1994), human capital theory has been identified as a prerequisite for economic development and countries have encouraged human capital accumulation to bring about growth. Based on the study done by these authors human capital accumulation affects economic growth in increasing the rate of domestically produced technological innovation and affects the speed of adopting to new technological innovations (Benhabib and Spiegal, 1994). Immigrants can bring different forms of human capital such as formal schooling, job experience and skills acquired through formal training to the receiving country (Chiswick and Miller, 2009). Canadian immigration policy focuses on bringing individuals with high human capital in order to have a strong labour market. Two important issues should be noted. One is that if immigrants are not able to use their obtained knowledge and skills effectively due to the systemic barriers, the Canadian government's attempt to transfer the individual human capital into its public domain in order to stay competitive in the global market has failed. The government's investment on the other hand on the existing human capital can bring the individual to an acceptable standard which can ensure the success of the immigration policies. According to Reitz (2005), the recent labour market outcomes contradict human capital theory. He claims that one of the reasons for the weakness of the human capital theory is the assumption that employers have effective means in assessing the productive value of immigrants' skills (Reitz, 2005). The labour market experience of immigrants in Canada is an example of an oversimplified application of human capital model. 
It is important to recognize that while immigrants belonging to different professions face many similar obstacles in the process of recognition of their credentials; their differences must also be acknowledged. This study will focus on the impact of the Federal Skilled Worker Program's (FSWP) point system on the labour market outcomes of a particular group of professionals: internationally trained dentists in Canada. The study will assess the employment status of internationally trained dental professionals who have entered Canada through the point system or who could potentially qualify under the points system. The study will be based on answers to a questionnaire completed by a group of internationally trained dentists who are going through the accreditation process in Canada. The purpose of the study is to see what challenges the dental professionals have faced and currently face after landing in Canada obtaining a license to practice. It will also examine how these challenges compare to what has been revealed in published research papers and government reports. The study will examine whether or not going through the process of exams and evaluations can guarantee success in this particular profession. The study will reveal difficulties of becoming a dentist in Canada by examining the individual internationally trained dentists' experiences in terms of the number of years they resided in Canada, the length of time taken to go through the accreditation process, the number of times they had to write the exams and how they paid for their living expenses while in school. 


\section{Chapter 2}

\section{Canada's Point System}

Canadian Immigration Policy has gone through many changes, including an increased focus on evaluating human capital using the point system under the economic class. Before the 1930s, Canadian immigration policy was designed to ensure an increase in its population, to generate economies of scale by bringing unskilled immigrants (Ferrer et, al, 2012: Grubel, 2013). Despite the cost and risks of ocean travel, immigrants from European countries with poor prospects and oppressive political conditions chose Canada as their new country in the hope of a better life (Grubel, 2013). Upon arriving in Canada, (for most of these European immigrants), unemployment was not an issue due to the fact that the growing Canadian economy was based largely on labour market focused on agriculture and resource extraction, which absorbed the incoming immigrants (Grubel, 2013). The government also helped newcomers with land grants in Western Canada and supported its construction of railroads, which provided employment and encouraged settlement (Grubel, 2013).

During the Great Depression unemployment and high economic stagnation affected the Canadian government's approach to immigration, which changed to only allow family reunification (Grubel, 2013). However, when the economy expanded after World War II, Canadian immigration policy changed once again to allow a larger number of Europeans into the country to meet the Canadian labour market demands (Grubel, 2013). According to Bouchard (2007), the focus of the Canadian immigration policy at this period was "the growth of population, higher living standards for Canadians and leav[ing] unchanged the basic characteristics of the population" (as cited in Grubel, 2013, p.3). 
Beginning in 1962, the non-discriminatory admission policy opened the door to immigrants from non-traditional source countries and from any racial background (Beach, Green $\&$ Worswick, 2006). The principle goal of the new policy was to eliminate discrimination in the admission of immigrants based on racial, religious and other group characteristics (Grubel, 2013). This universal immigration policy was a response to shift the labour force towards an urban, industrialized economy (Beach et al. 2006). The point system, implemented in 1967 under the Immigration Act of 1952, focused on human capital, It was designed to measure the admissibly of prospective immigrants and has since been revised, yet the core of the assessment has remained the same (Beach et al. 2006). By focusing on human capital, the policy aims to ensure the employability of immigrants in an economy where hidden skilled labour is an emerging priority (Reitz, 2002, p. 101). The increased number of immigrants with education or professional experience admitted to Canada since the 1970s is due to the implementation of the point system (Remennick, 2013). These immigrants moved to the Western world as a result of the "demise of the socialist system in east-central Europe and economic awakening of the mainland china and other East Asian nations in the late 1980s and 1990s" (Remennick, 2013, p.152-153).

Hawthorne (2007) explains that most of the recent economic class of immigration has consisted of highly educated persons. The 2001 Census indicated that 3,374,057 immigrants had degrees and 3,801,118 had post secondary diplomas and certificates (Hawthorne, 2007). Also, according to 2001Census data, between 1996 and 2001, twice as many newly arrived immigrants had a degree compared to the Canadian-born (Hawthorne, 2007). In the past decade, one third of the 1.2 million immigrants who have arrived to Canada held a professional qualification and $50 \%$ of their target fields require some type of training or formal credential (Hawthorne, 2007). 
While only $15 \%$ of Canada's occupations are regulated, $34 \%$ of immigrants who arrived between 1996 and 2005 were trained to work in these regulated professions (Hawthorne, 2007). In 2001, $22 \%$ of the total Canadian IT workforce, $20 \%$ of all engineers and $16 \%$ of architects were recent immigrants who had been in Canada for five years or less (Hawthorne, 2007, p.4). Hawthorne (2007, p.4) concludes that the suddenness of these inflows posed a clear risk of "flooding the market" had their professional credentials allowed them to immediately practice. More recent data indicates that in 2008 close to $45 \%$ of immigrants held a university degree; $72 \%$ of the main applicants in the skilled worker category and $41 \%$ of their spouses (Houle and Yssade, 2010, p.18).

A comparison of the number of points allocated to different categories of selection factors under the Federal Skilled Worker Program (FSWP) reflects the emphasis that has been put on education. A passing grade, which had remained the same at 50 out of 100 from 1967 to 1985, increased to 70 out of 100 in 1985 (Reitz, 2002, p. 106; Green \& Green, 2004). As demonstrated in Table 1, the point allocation for education was 20 in 1967 and stayed the same until 1977 (Green \& Green, 2004). The emphasis on education decreased between 1978 and 1995 and was increased again in 1996 (Table 1). In 2001, the point allocation changed from (number of points) to 34 points for education and training (Reitz 2002, p.107). These changes to the points system were introduced based on premise that education was the most important element of human capital. (Alboim, Finnie \& Meng 2005). According to the Citizenship and Immigration Canada (2013) website, the Federal Skilled Workers program measures the applicants in 6 categories. These categories are "work experience, education, language, age, arranged employment and adaptability, elements that involve factors such as a positive arranged 
employment opinion, spousal (partner's) education, family relations in Canada, post-secondary study and work experience in Canada" (CIC, 2013).

Table 1: The Points System Over Time (Number of points varies in each category) ${ }^{1}$

\begin{tabular}{|l|c|c|c|c|c|c|}
\hline Factor & $\mathbf{1 9 6 7}$ & $\mathbf{1 9 7 4}$ & $\mathbf{1 9 7 8}$ & $\mathbf{1 9 8 6}$ & $\mathbf{1 9 9 3}$ & $\mathbf{1 9 9 6}$ \\
\hline & & & & & & \\
\hline Education & 20 & 20 & 12 & 12 & 15 & 20 \\
\hline Experience & - & - & 8 & 8 & 8 & 9 \\
\hline & & & & & & \\
\hline $\begin{array}{l}\text { Specific Vocational } \\
\text { Preparation }\end{array}$ & 10 & 10 & 15 & 15 & 17 & - \\
\hline Occupational Demand & 15 & 15 & 15 & 10 & 10 & - \\
\hline Labour Market Balance & - & - & - & - & - & 10 \\
\hline & & & & & & 12 \\
\hline Age & 10 & 10 & 10 & 10 & 10 & \\
\hline & & & & & & 20 \\
\hline $\begin{array}{l}\text { Arranged Employment or } \\
\text { Designated Occupation }\end{array}$ & 10 & 10 & 10 & 10 & 10 & 16 \\
\hline Language & 10 & 10 & 10 & 15 & 14 & \\
\hline Personal Suitability & 15 & 15 & 10 & 10 & 10 & \\
\hline & & & & & & \\
\hline Levels & - & - & - & 10 & 8 & \\
\hline Relatives & $0 / 3 / 5$ & $0 / 3 / 5$ & 5 & - & - & \\
\hline Destination & 5 & 5 & 5 & - & - & \\
\hline & & & & & & \\
\hline Total & 100 & 100 & 100 & 100 & 100 & 100 \\
\hline Pass Mark & 50 & 50 & 50 & 70 & 67 & \\
\hline
\end{tabular}

\footnotetext{
1 Source: Green, A. G., \& Green, D. (2004). THE GOALS OF CANADA'S IMMIGRATION POLICY: A HISTORICAL PERSPECTIVE. Canadian Journal of Urban Research, 13(1), 102-139. Retrieved from http://ezproxy.lib.ryerson.ca/login?url=http://search.proquest.com/docview/208718414?accountid=13631
} 
The most recent selection factors for the Federal Skilled Worker program awarded a total of 53 points for language ability and education (CIC, 2013). As indicated in table 2, applicants are awarded up to 25 points for education and up to 15 points for experience (CIC, 2013). Also as indicated in Table 2, language proficiency in English and/ or French has been increased from 20 in 1996 to 25 in 2011 and 28 in 2013 . These changes and the emphasis on education and language ability signify that Canada wants to ensure that newcomers will be able to use their education and language skills to find employment quickly. While points allocated for experience are still high, the fact that they have a lower value than education and language proficiency signifies that past experience cannot guarantee a positive outcome unless the applicant has the other two factors. This shift in policy aims to speed the process of integration of the new immigrants by ensuring that they are ready to enter the labour market upon arriving in Canada. Table 2: The Points System- 2011 and $2013^{2}$

\begin{tabular}{|l|c|c|}
\hline \multicolumn{3}{|l|}{ The Points System- recent } \\
\hline Factor & $\mathbf{2 0 1 1}$ & $\mathbf{2 0 1 3}$ \\
\hline $\begin{array}{l}\text { English and/or } \\
\text { French Skills }\end{array}$ & 24 & 28 \\
\hline Education & 25 & 25 \\
\hline Experience & 21 & 15 \\
\hline Age & 10 & 12 \\
\hline $\begin{array}{l}\text { Arranged } \\
\text { Employment in } \\
\text { Canada }\end{array}$ & 10 & 10 \\
\hline Adaptability & 10 & 10 \\
\hline Total & 100 & 100 \\
\hline $\begin{array}{l}\text { Pass Mark: } 67 \text { out of } 100 \\
\text { Points }\end{array}$ \\
\hline
\end{tabular}

${ }^{2}$ Sources: Citizenship and Immigration Canada (2009). Six selection factors - Federal skilled workers. Retrieved from http://www.healthcentral.com/heart-disease/patient-guide-44510-6.html.

Canada Updates. (2011) Canada'spoints system for selecting immigrants 2011. Retrieved from http://www.canadaupdates.com/content/Canada-skilled-worker-imigration-ponits-based-immigration 
The Economic Action Plan (2012) emphasised that changes to the point system are a shift toward placing more importance to younger immigrants with better language skills. (The Point System) Some researchers have identified language ability as the most important factor for immigrants' success (Newson, 2013). In fact, short-term labour market objectives have been replaced by strengthening the "human capital" model of immigration that rewards skills such as education, experience and language ability even higher (Ferrer et, al, 2012). Ottawa declared in a news release in May 2013 that Canada is now seeking immigrants who are not only "most needed by our economy, but that they are best positioned for success" (CIC, 2013a). One of the major changes mentioned is the introduction of the Educational Credential Assessment (ECA) program to evaluate foreign education based on its true value in Canada (CIC, 2013b). The purpose of the ECA is to give the applicants a realistic understanding of whether or not their credentials will be recognized in Canada (CIC, 2013b). CIC has designated the following four organizations to do the assessment: the Comparative Education Service at University of Toronto School of Continuing Studies; the International Credential Assessment Service of Canada; the World Education Services; and, the Medical Council of Canada (CIC, 2013b). In addition, Since May 2013, to be eligible to apply to the FSW program, applicants must have experience in one of the 24 eligible occupations (Appendix 1), have an arranged employment offer, or be eligible to apply through the PHD stream (CIC, 2013b). It is not clear what the implications of the changes to the immigration policy will be for the immigrants with foreign accreditation and whether or not these changes will make it easier for them to enter the labour market. However, the current list of eligible occupations reflects the restrictiveness of recent changes to the immigration policy. Many potential candidates, who were eligible under the previous system, are not eligible to apply under these changes. 


\section{The Employment Outcomes of Professionals}

Although the Federal Skilled Worker Program has targeted higher educated and skilled immigrants for decades, the difficulties immigrants face entering the labour market and the positions they hold after many years of employment, remain a major issue. Many immigrants discover that their education has been discounted upon arrival in Canada and this has made it challenging for them to land jobs similar to the ones they had in their country of origin. To understand the outcome of making education a major determinant in immigrant selection, it is important to look at the level of recognition of the immigrants' education by employers and the earnings of immigrants after their arrival in Canada. Employers appear to remain uncertain regarding the value of foreign obtained credentials and experiences. It is often challenging for employers to determine whether or not the acquired skills meet Canadian standards (Papademetriou and Sumption 2011). Part of the challenge is that because employers have limited means of measuring foreign education and the standings of international universities, the value of foreign education is discounted (Alboim et al. 2005, Alboim\&McIsaac, 2007). Alboim et al. (2005) argue that the prejudice that exists toward foreign credentials can be as a result of the inability of Canadians to judge the worth of foreign degrees. The ECA, mentioned in the previous section, could make the assessment of immigrants' credentials easier for the employers in the labour market in the future by providing a better understanding of where the immigrants stand in terms of Canada's ranking of education and the labour market.

The inconsistency between the point system and the true earning power of foreign obtained education has been evident in the Canadian labour market (Albiom et al. 2005). Since the 1970s, the employment rates and earnings of immigrants have declined and recent immigrants are among the most affected groups (Reitz, 2012). Clearly, the discounting of 
foreign education has led to lower earning among immigrants. However, Reitz (2012) argues that the recession at the end of 1980s and the weak employment demand of early 1990s were also responsible for the decline in earning of immigrants. Nevertheless, research indicates that there is a 30 percent earning disadvantage among immigrants (Alboim, et al. 2005). Despite the fact that immigrants' labour market participation is only 3.5\% lower than the Canadian-born (King, 2009) and immigrants have a higher rate of education than Canadian- born, new immigrants still earn less than the Canadian born. Based on Canada Census data, immigrants earn \$2.4 billion less than native-born Canadians with comparable skills as they work in occupations below their skill level (Reitz, 2005). Looking at immigrants' skills sets demonstrate that while two third of these skills are transferable to Canada; they are still not being utilized (Reitz, 2005). The belief that the immigrants' skills are transferable assumes that there is no skill gap between the source country and the host country (Imai et al. 2011). The labour market outcomes of immigrants in recent years shows that assuming higher education can simply be transferred to the destination country, without consideration of the existing barriers, poses new challenges for Canadian society as a whole.

The point system till now has only assessed the quantitative abilities of the applicants and has frequently failed to measure the quality or utility of their skill or education (Papademetriou \& Sumption 2011). Regulated professions are the bodies that formally assess foreign education after the immigrants' arrival if they are approached by the immigrant. There are some professions which are regulated in Ontario to protect public health and safety (Ontario Council of Agencies Serving Immigrants, 2014). "Currently 14 non-health professions and 22 compulsory trades are covered by the Fair Access to Regulated Professions and Compulsory Trades Act, 2006, and 26 health professions are covered by the Regulated Health Professions Act, 1991, as 
amended" (Queen's Printer for Ontario, 2014, Paragraph 1). According to an analysis of the employment of professionals based on census 2006 data, only $24 \%$ of immigrants worked in regulated professions matching their qualifications as opposed to $62 \%$ of the Canadian born (Houle and Yassad, 2010). Research indicates that once the immigrants obtain Canadian education and experience, their earnings soon catch up to Canadian born levels (Alboim et al. 2005, Alboim \& McIsaac 2007). In fact, combining Canadian education with foreign education increases the value of the Canadian education (Alboim et al. 2005; Alboim \& McIsaac 2007). While these positive outcomes reveal the importance of professional regulatory bodies in the process of evaluating foreign credentials, it is important to understand the implications of going through the process. Improving the process would affect the labour market outcomes of immigrants. The negative economic impact of labour market barriers such as the costs of applications for licensing or the length of time spent in training courses are significant. The underutilization of immigrants' skills can lead to disappointment for the immigrants since they are selected on the basis of higher education pre-arrival but are forced to deal with the negative outcomes of lack of recognition of their education by professional accreditation bodies during their settlement in Canada (Alboim et al. 2005). 


\section{Chapter 3}

\section{Foreign Credential Recognition in Canada}

Foreign Credential Recognition (FCR) has been defined by Employment and Social Development Canada (ESDC) as "the process of verifying that the education and job experience obtained in another country are equal to standards in Canada. Workers should have the freedom to practice their occupation wherever opportunities exist, whether they were certified in Canada or in another country. This is also known as Labour Mobility" (ESDC, 2013a, Paragraph 1). According to Alboim and McIsaac (2007), there are three reasons why immigrants may need their credentials assessed: "to continue their education at the appropriate level; to gain licensure for a particular trade or profession; and/or to find employment" (Alboim \& McIsaac, 2007, p.16). The accreditation of foreign credentials is not unique to Canada and is not a recent phenomenon (Newson, 2013). The Foreign Credential Referral Office (FCRO) is a department within Citizenship and Immigration Canada and provides information, path-finding and referral services on foreign credential recognition, as well as provides funding for projects to help internationally trained workers succeed and put their skills to work in Canada more quickly (CIC, 2013c). "FCRO's services help internationally trained workers reach their potential and their mandate is to guide, monitor and facilitate the implementation of the foreign credential recognition process" (CIC, 2011). Some of the FCRO's initiatives are: the International Qualifications Network (IQN), which is a website to catalogue the successful practices on foreign credential recognition for regulated and non- regulated professions; the Federal Internship for Newcomers Program, which provides temporary internships to newcomers to help them enter the Canadian labour market; the Pan-Canadian Framework for the Assessment and Recognition of Foreign Qualifications, which looks at how to improve processes for assessing and recognizing foreign 
credentials in Canada through cooperation of all levels of government; and the In-person service at Service Canada, which provides in person and dedicated telephone on behalf of FCRO (CIC, 2011).

Provincial and territorial bodies regulate trades and professions in Canada and have the power to regulate the professional labour market for the corresponding professions (Girard and Bauder, 2007). "Most professions are governed by an association or college which consists of all the professionals in the province or territory" (Canadian Network of National Associations of Regulators, 2014). A council consisting of professionals and public representatives acts as the head of the association or collage (CNNAR, 2014). These self-governing bodies determine who is allowed to practice in a profession in Canada and grant licensure to those who meet their requirements (Girard and Bauder, 2007). The professions govern by these bodies determine the scope of practice and set standards of education and of ethical competent practice or profession led process (CNNAR, 2014). Internationally trained professionals must apply to the relevant provincial or territorial professional college or association in Canada for permission to practice and get assessed by regulatory body to determine eligibility to practice (CNNAR, 2014).

There are many services and websites available for immigrants with foreign credentials. One of the biggest ones, the Canadian Information Centre for International Credentials (CICIC) is a unit of the Council of Ministers of Education- Canada (CMEC), an intergovernmental body founded in 1967 by ministers of education that offers "information and referrals services to individuals and organizations on the recognition of academic and occupational credentials for working and studying in Canada and abroad" (2014, Paragraph 2). There is extensive information and links to different regulatory bodies and organizations regarding credential assessment for specific occupations on the CICIC website but explaining them in detail is 
beyond the scope of this paper. In addition, many agencies provide services such as credential assessment, bridge training programs and internships to immigrants to gain Canadian experience and mentorship systems to help them build a wider network with people in their own fields (Reitz, 2012). The World Education Service (WES) (2014) is one of the widely accepted nonprofit organizations that evaluate education credentials. The assessments focus on equivalencies between the immigrants' training abroad and the training undergone by Canadian educated professionals (Reitz, 2012). The immigrants seeking assessment of their credentials are required to pay a fee depending on the extent of the service they require. Reitz (2012) assumes a WES assessment has a positive impact as immigrants are willing to pay the amount. One could argue that the immigrants do not have a choice but to get their credentials evaluated in order to find out where they stand. Settlement organizations also play an important role in providing face-to-face information to immigrants. It is important to note that the government provides funding to the settlement sector and some of the organizations handling foreign credential assessment, but not to individuals seeking the services. It is evident that immigrants seeking FCR services have access to a wide variety of services in terms of getting the appropriate information, as well as receive support choosing which organization, school or regulatory body to approach. Approaching the regulatory body specific to their profession directly will make the process of gathering information on credential recognition more clearly and prevent confusion for the individual seeking the service.

\section{Foreign Credential Recognition Barriers:}

In a 2011 progress report, the Government of Canada acknowledged that the process of assessment and recognition of foreign credentials is a barrier to the labour market integration of many internationally trained individuals. Recognizing the complexity of the matter has led the 
Human Resources and Skills Development Canada (HRSDC), Citizenship and Immigration Canada (CIC), and Health Canada to work together to address labour market integration issues for internationally trained individuals (CIC, 2012). Some of the existing problems addressed by the government are: there are few partnerships across provinces to help the assessment process, great variation exists between bodies and provinces assessment strategy, and an in depth policy response is still required (Hawthrone, 2007). The recognition of credential is a shared responsibility of the three federal, provincial and territorial governments (Ikura, 2007). There are 5 provincial assessment agencies, more than 400 regulatory bodies, over 200 accredited post secondary institutions and a myriad of employers (Ikura, 2007). Provincial and territorial governments have constitutional authority for regulating most professions and have delegated certain rights such as determining licensing and certification to regulatory bodies (HRSDC, 2007). Also, the provinces and territories regulate skilled trade, but not non- regulated occupations (HRSDC, 2007).

The bodies involved in the credential assessment process tend to use various methods to assess international education. Some focus on the formal recognition of credentials, while other bodies do informal assessment (Ikura, 2007). Each of these bodies has a different purpose and strategy in the method of assessment they choose (Ikura, 2007; CIC, 2013b). For example, post secondary institutions' assessments are for academic placement, while the regulatory bodies do it for licensure or certification (Ikura, 2007). Therefore, some professionals have to approach these bodies separately and spend extra money to get their degrees assessed. In addition, the provinces and territories may require different documentations to meet their provincial standards (CIC, 2013b). The overlap in the work of some of the bodies is another issue (Ikura, 2007). These inconsistencies lead to a waste of resources as the credential assessment is reinvented from one 
province to another and from one regulatory body to another (Alboim \& McIsaac, 2007). Methods of collaboration should be practiced to avoid overlapping in the work of bodies. For example Alberta's provincial assessment agency, the International Qualifications Assessment Services (IQAS), works with provincial secondary institutions to speed up the process of assessment for post secondary entrance (Ikura, 2007).

The issue of choosing a credential recognition body creates difficulties for the immigrants. A research study focusing on engineers shows that the participants who got their assessment done through a professional body were fully accepted by the employers, professional bodies and immigration officers (Chaze \& George, 2012). On the other hand, those who assessed their credentials through educational institutions were not fully or even partially accepted by the employers, professional bodies and immigration officers and only to some degree recognized by the educational institutions (Chaze \& George, 2012). The three main conclusions drawn from the research were: the engineers were not fully aware of the process of foreign credential assessment prior to arrival in Canada; the ambiguity of the assessment process in some cases led the engineers to have their credentials assessed multiple times by different bodies; and the engineers faced different outcomes depending on which body they approached for the credential assessment and the professional bodies' assessment was more useful than educational institutions in securing a job (Chaze \& George, 2012).

While internationally trained professionals (ITP's) can approach the specific body regulating their professions for information and evaluation, they may face difficulties in the process of credential recognition. These individuals have to go through formal recognition of their skills and credentials (Boyd \& Schellenberg, 2007; Newson, 2013), which may involve exams, more schooling and residency programs depending on the requirements of the regulatory 
body for licensing. Also, ITP's face rigorous institutional procedures to evaluate their education and professional work experience (Reitz, 2003). The importance regulatory bodies attach to a specific education- based professional skill determines the nature of the assessment procedures (Reitz, 2003).

For public safety reasons, both Canadians seeking to enter a profession as well as immigrants must train in a recognized program of study, have a high command of the professional language required for the field and validated experience (Boyd \& Schellenberg, 2007). Research shows that, it takes 10 years for some ITP's to match their Canadian-born counterparts in earning (CIC, 2008, paragraph 1). The cost of the extra training and credential recognition, coupled with the long process of licensing forces many immigrants to choose alternative occupations (Mcdonald, Warman \& Worswick, 2011). One striking data in the 2001 census indicated that $55 \%$ of internationally educated doctors were practicing as opposed to $90 \%$ of their Canadian counterparts; and 33\% of the foreign trained doctors were employed in occupations completely unrelated to health care (Boyd \& Schellenberg, 2007). Schwartz and Dhillon- Penner (2009) argue that since self- regulatory bodies need to acknowledge the interests of their private members, they hold monopolies to ensure large workloads and high wages for their industries. Medical professionals are one of the groups majorly affected by this sort of protectionist approach that limits the supply and competition within the occupation (Newson, 2013).

A major challenge for ITP's in the recognition of foreign credentials in Canada is lack of financial aid and human resources of the institutions (Ikura, 2007). The lengthy and costly process of accreditation includes application costs, registration and licensing fees, as well as indirect costs such as transcripts' requests and academic records, certified translation of 
documents, verification services for authenticity and courier costs (Newson, 2013). Since many immigrants face unemployment or underemployment in the first few years of immigration, the high financial burden of accreditation process can have long-term implications for their families (Newson, 2013). The Summative Evaluation of the FCRP in April 2010 indicated many professional accreditations in occupations such as teaching, dentistry, and psychology did not receive FCR funding (ESDC, 2013b). While many government bodies provide a lot of information to immigrants about accreditation, other kinds of support such as financial or psychological is limited depending on the profession ${ }^{3}$. Sumpton (2013) recommends that introducing innovative approaches such as online training and providing low cost student loans could be beneficial.

Language proficiency is another major barrier in the foreign credential recognition process. Based on a research done CIC (2010) looking at the impact of IRPA on economic outcomes of FSW immigrants identifies language as the second most important element in employability of immigrants. Applicants scoring between 16 and 20 in language ability have $38 \%$ to 39\% higher earnings than FSWs who received scores between 0 to 7 points for language (CIC, 2010, Section-3.6-The effectiveness of selection criteria for FSWP). For public safety reasons, Canadian professionals, as well as immigrants, must train in a recognized program of study and acquire high command of professional language required for the field (Boyd \& Schellenberg, 2007). The required language scores for getting into a Canadian university and/or licensing are very high, and immigrants may need a few years to become proficient. Language

\footnotetext{
3 The psychological impacts of going through the credential assessment can lead to stress and health conditions. The loss of social status and self- esteem is a major psychological consequence of immigration (Newson, 2013). While psychological problems immigrants face are significant, it is beyond the scope of this research to provide further details.
} 
training is a part of Canadian immigration policy's integration program (Reitz, 2012). Rietz (2012) points out "total federal expenditures for the Language Instruction for Newcomers to Canada (LINC) program were nearly C $\$ 100$ million (according to an evaluation report dated 2009 and posted on the CIC website)". As pointed earlier in Chapter two, the most recent changes to immigration policy included an increase in the points assigned to language proficiency under the FSW program. This indicates that the Canadian government is making an attempt to bring in immigrants who are closer to meeting the language requirements, which in the long run will save the government from investing in language training programs. While the effects of these changes are yet to be seen, it is clear that bringing more immigrants under the economic class who are highly skilled and have higher language ability will also affect the settlement programs offered to newcomers in the long run. It is hoped that this shift in language policy will lead to better employment opportunities for FWS's upon their arrival to Canada. 


\section{Chapter 4}

\section{Licensing process of Internationally Trained Dentists in Canada}

Similar to many other professionals internationally trained dentists are required to go through a strict licensing process in order to be able to practice in Canada. Dental licensure in Canada is a provincial responsibility handled by dental regulatory authority/licensing bodies in each province/ territory that establish regulations and requirements for the licensure of general practitioners within their jurisdiction (Canadian Dental Association, 2014). Established in 1868, the Royal College of Dental Surgeons of Ontario (RCDSO, 2014) is the body responsible for regulating the dentistry profession in the province of Ontario. A non- Canadian or non- US trained dentist can acquire a license/ registration by 1) completing an accredited dental program, as a regular or degree completion student, or 2) completing an accredited qualifying program or completing the Equivalency Process offered by the National Dental Examining Board of Canada (NDEB) (Canadian Dental Association, 2014; Association of Canadian Faculties of Dentistry, 2014; Royal Collage of Dental Surgeons of Ontario, 2014).

All dental programs are accredited by the Commission on Dental Accreditation of Canada (CDAC) (2013) or the American Dental Association Commission on Dental Accreditation. There are also a few other general dentistry programs that are accredited in Canada: effective March 30, 2010, the general dentistry programs accredited by Australian Dental Council (ADC); effective December 15, 2011, the Dental Council of New Zealand (DCNZ); and/ or effective December 5, 2012, the Irish Dental Council (CDAC, 2013). The dental graduates of these accredited programs are only required to complete the National Dental Examining Board of Canada Written Examination and Objective Structured Clinical Examination (OSCE) for certification as a general dentist in Canada (AFCD, 2014). 
International dentists can refer to the NDEB website for information on the reaccreditation process. The website offers detailed information on the type of tests and the protocols. Also, the website explains the process of how to complete an accredited qualifying or degree completion program or the NDEB Equivalency Process, which are the two possible pathways for internationally trained dentists to get a dental license in Canada as an internationally trained dentist (RCDSO, 2014). (Appendix 2) The website offers a web based self assessment, information and document verification that leads to Equivalency Process (RCDSO, 2014). The Equivalency Process is an alternate route for internationally trained dentists, which requires the successful completion of three assessments: written, clinical and judgment exams. Passing the three exams will allow the internationally trained dentists to apply to take the NDEB Written and OSCE Examinations which is often informally referred to as the board exam. After passing the board exam, they are eligible for a license. The Assessment of Fundamental Knowledge, (with a minimum score requirement of 75) has a multiple choice format which is the first step in meeting the standards for other assessments (RCDSO, 2014). Also, this assessment exam is the requirement for the dental qualifying program offered by schools that will be explained further. The next step is two days of Assessment of Clinical Skills offered three times within a three year period to applicants who have passed Assessment of Fundamental Knowledge (RCDSO, 2014). Finally, the Assessment of Clinical Judgement, another multiple choice format exam, which takes one day to complete, is also required as well (RCDSO, 2014).

The NDEB websites offers past assessment results which indicate the difficulty of the licensing process. In 2011, 44 percent of the 821 applicants who wrote the Assessment of Fundamental Knowledge exam passed. In the same year, 23 percent of the 266 applicants who 
took the Assessment of Clinical Skills exam passed and 50 percent of the 289 applicants who wrote the Assessment of Clinical Judgment exam passed (NDEB, 2014). In 2012, the numbers of applicants in all three groups increased while the percentage of those who succeeded in two categories decreased. Out of 1125 applicants who wrote the Assessment of Fundamental Knowledge exam, 36 percent passed; out of 359 applicants who wrote the Assessment of Clinical Judgment exam 36 percent passed, and out of 373 participants of Assessment of Clinical Skills exam 65 percent passed (NDEB, 2014). Similarly in 2013, the numbers of participants in all three groups increased while the percentage of those who succeeded in two categories decreased. Out of 1187 applicants who wrote the Assessment of Fundamental Knowledge exam, 42 percent passed; out of 483 applicants who wrote the Assessment of Clinical Judgment exam 26 percent passed and out of 493 participants who wrote the Assessment of Clinical Skills exam 59 percent passed (NDEB, 2014). Also, past assessment results show that 44 dentists in 2011, 127 dentists in 2012 and 143 dentists in 2014 successfully completed the Equivalency Process (NDEB, 2014). It is not clear how many dentists had taken the exams and what percentage was successful. (Table 3)

Table 3: Summary of Historical Pass Rates for the NDEB Equivalency Process ${ }^{4}$

\begin{tabular}{|r|r|r|r|r|r|r|}
\hline & \multicolumn{2}{|c|}{ AFK } & \multicolumn{2}{c|}{ ACS } & \multicolumn{2}{c|}{ ACJ } \\
\hline YEAR & $\begin{array}{c}\text { TOTAL \# OF } \\
\text { PARTICIPANTS }\end{array}$ & \multicolumn{1}{c|}{$\begin{array}{c}\text { PASS } \\
\text { PATAL \# OF }\end{array}$} & $\begin{array}{c}\text { TOTTICIPANTS } \\
\text { PASS }\end{array}$ & $\begin{array}{c}\text { TOTAL \# OF } \\
\text { PARTICIPANTS }\end{array}$ & $\begin{array}{c}\% \\
\text { PASS }\end{array}$ \\
\hline 2011 & 821 & 44 & 266 & 23 & 289 & 50 \\
\hline 2012 & 1125 & 36 & 359 & 36 & 373 & 65 \\
\hline 2013 & 1187 & 42 & 483 & 26 & 493 & 59 \\
\hline
\end{tabular}

\footnotetext{
${ }^{4}$ Source: National Dental Examining Board of Canada. (2014). Summary of historical pass rates for the ndeb equivalency process. Retrieved from http://www.ndeb.ca/nonaccredited/past-assessment-results
} 
The other pathway of getting a license to practice for a foreign trained dentist is applying to a university to complete the qualifying program. Internationally trained dentists who pass the Assessment of Fundamental Knowledge exam with a score higher than 75, have proof of achievement of an appropriate standard in a recognized test of English facility such a TOFEL, IELTS or MELAB, in addition to other requirements specific to different schools, are eligible to apply to qualifying programs offered by the eight dental schools in Canada (RCDSO, 2014). (Appendix 3) While each of these programs may have specific requirements for entry into the program, the main requirements such as exam results and language proficiency scores applies to all. Total admissions in dental schools offering Qualifying and degree Completion programs were 70 in 2011, 80 in 2012 and 91 in 2013 (NDEB, 2014).

Dental schools in Canada are very competitive and the seats are very limited both for Canadian students and internationally trained. For example, the University Of Toronto Faculty Of Dentistry's (2014) requirements for the International Dentist Advanced Placement Program (IDAPP) are as follows: ("International dentist advanced," 2013)

The applicants must:

- have graduated from a four-year university dental program not recognized by CDAC with a minimum grade point average of 3 (on a scale of 4 ),

- have notarized copies of transcript and dental school diplomas,

- fulfill the English requirement as well as the Assessment of Fundamental Knowledge with a competitive score taken within a two year period.

(Source: "International dentist advanced," 2014) 
After reviewing the application, some applicants will be called for 30 minute interviews for admission into the IDAP Program ("International dentist advanced," 2014). According to the admission office of Faculty of Dentistry, University of Toronto (personal communication, December 19, 2013) approximately 200 people apply to IDAP Program each year but only 30 spaces are available.

Another major issue for the foreign trained dentists is the high cost of the licensing process. The fees for the examinations and admission to the dental programs are very high. Some of the costs involved are:

- The tuition and associated expenses for two years of university in the Qualifying Advanced Standing International Dentist Program ranges from $\$ 90,000$ to $\$ 140,000$. (RCDSO, 2014)

- The NDEB Equivalency Process fee is approximately $\$ 8,000$

- The National Dental Examining Board charges approximately $\$ 2000$ for the examination. (RCDSO, 2014)

- Many foreign trained dentists take private classes offered by training centres to prepare for the exams and interviews. The costs of these courses vary from $\$ 250$ to over \$5000 each (Dental Simulation Training Center, 2014).

Considering that they cannot get student loans to pay for these courses, these costs become a major burden on the dentists and their families. In addition to these costs, living expenses for themselves and their families is another challenge. The foreign trained dentists have to spend a lot of time preparing for the exams. Therefore, they have limited opportunities to seek employment in other sectors. 
While looking at the long process of accreditation of internationally trained dentists has revealed the complexity and the high costs of the process for this group of immigrants, it is important to assess these challenges by examining their thoughts, opinions and experiences. The next sections of this study will assess the responses of internationally trained dentists residing in Ontario who have completed a survey which asked questions focusing on the above mentioned processes and challenges. 


\section{Chapter 5}

\section{Methodology}

This study follows a quantitative research approach. The survey was conducted with the approval of the Ethics Board at Ryerson University (REB 2014-066). The purpose of this research survey is to gain a better understanding of the accreditation process of internationally trained dentists who have been admitted to Canada as Federal Skilled immigrants and how this process affects their employment outcome. Since there has been no previous study done looking at this process, the survey seeks to shed some light on issues affecting internationally trained dentists by analysing the responses of individual dentists going through the licensing process.

\section{Research Design}

The project made use of a cross-sectional survey designed to gather information from 52 internationally trained dentists. The researcher administered this questionnaire to the group once in March 2014 and there was no follow-up test. The questionnaire mainly consisted of closedended questions about issues specific to the credential recognition of internationally trained dentists in Canada (See Appendix 4 for the survey). In order to give participants a chance to express their personal views on the topic or address any issue that was neglected by the researcher, one optional open-ended question was included in the survey. Also, some questions were designed to identify differences in accreditation experiences between those who had successfully entered a qualifying program at a university and those who were still in the process of going through exams and were uncertain about the outcome. The variables were certain participant characteristics, such as the country of origin and the immigration program they came under. The survey questionnaire was designed to answer questions on the demographics of the 
participants, the immigration program they came under, the number of years they have lived in Canada, their experience with licensing exams, the costs involved and their method of obtaining money to pay for living expenses as well as their experiences in regard to obtaining information.

\section{Participants}

The 52 participants (24 males and 28 females) of this study compared two groups of internationally trained general dentists. All except one from Europe came from different countries in Asia and are permanent residents or Canadian citizens living in the Greater Toronto Area (GTA). One group which was recruited from the Faculty of Dentistry, University of Toronto, had been accepted into the qualifying program, were completing it and were on their way to licensing. The other group, which was recruited from training centres ${ }^{5}$, consisted of those who were still preparing and/ or writing exams and were trying to meet the requirements to apply to the qualifying program of universities or to the Equivalency Process. Internationally trained dentists who were seeking to acquire a Dental Specialty license were excluded from the survey since their pathway to licensing is different from general dentists. Participants were assured of anonymity at the time of testing.

\section{Data Collection and Analysis}

The survey questionnaires were handed to participants by the researcher and were picked up a week later. Descriptive statistics based on the collected data were used to calculate the average response of participants. Univariate analysis was used to examine group differences in the outcome variables.

\footnotetext{
${ }^{5}$ Training Centres are privately operated institutions that offer preparatory didactic packages, hands-on practical instruction, and patient management guidance, designed to meet the licensing requirements.
} 


\section{Chapter 6}

\section{Results}

A total of 52 internationally trained dentists completed the survey. Data related to the age and gender of participants is summarized in table 4 . In summary, $62 \%(n=32)$ of the participants were under 40 years of age, $38 \%(n=20)$ were over 40 years of age and $10 \%$ were over 50 years of age. In addition, $46 \%$ of the participants were male and $54 \%$ were female.

Table 4) Age and gender distribution of the participants

\begin{tabular}{|l|l|l|l|l|l|l|l|}
\hline $\begin{array}{l}\text { Age } \\
\text { (years) }\end{array}$ & $25-29$ & $30-34$ & $35-39$ & $40-44$ & $45-49$ & $50+$ & Total \\
\hline Male & 2 & 10 & 3 & 4 & 3 & 2 & 24 \\
\hline Female & 7 & 8 & 2 & 6 & 2 & 3 & 28 \\
\hline Total & 9 & 18 & 5 & 10 & 5 & 5 & 52 \\
\hline
\end{tabular}

The following table 5 presents the country of origin of the participants as well as the immigration program that admitted them to Canada. In summary, $19 \%$ of the participants had immigrated to Canada under the family sponsorship program ( $\mathrm{n}=10,8$ females and 2 males). $71 \%$ of the participants immigrated to Canada under Federal Skilled Worker Program ( $\mathrm{n}=37,18$ females and 19 males) and $8 \%$ of the participants immigrated to Canada under Investor, entrepreneur and self-employed program ( $\mathrm{n}=4,2$ females and 2 males). Only $2 \%$ ( $\mathrm{n}=1$ male) had arrived to Canada under the Provincial Nominee Program. In total, $81 \%$ of the international dentists who participated in the survey had come to Canada under the economic class. Also, the data on the country of origin of the participants reveals that majority of them are from Asia. 
Table 5) Country of Origin and the Immigration Program

\begin{tabular}{|c|c|c|c|c|c|}
\hline Canadian Immigration Program & $\begin{array}{l}\text { Country of } \\
\text { Origin }\end{array}$ & $\begin{array}{l}\text { Dental degree } \\
\text { obtained from }\end{array}$ & $\mathbf{F}$ & $\mathbf{M}$ & $\begin{array}{l}\text { Grand } \\
\text { Total }\end{array}$ \\
\hline \multirow[t]{7}{*}{ Family Sponsorship } & Egypt & Egypt & 1 & & 1 \\
\hline & India & India & 2 & 1 & 3 \\
\hline & Iran & Iran & 1 & & 1 \\
\hline & Pakistan & Pakistan & 2 & & 2 \\
\hline & Romania & Romania & 1 & & 1 \\
\hline & Sri Lanka & Sri Lanka & 1 & & 1 \\
\hline & Turkey & Turkey & & 1 & 1 \\
\hline \multicolumn{3}{|l|}{ Family Sponsorship Total } & 8 & 2 & 10 \\
\hline \multirow[t]{8}{*}{ Federal Skilled Worker } & China & China & 3 & 2 & 5 \\
\hline & Egypt & Egypt & & 1 & 1 \\
\hline & India & India & 6 & 6 & 12 \\
\hline & Iran & Hungary & 1 & & 1 \\
\hline & & Iran & 6 & 7 & 13 \\
\hline & Nepal & Nepal & & 2 & 2 \\
\hline & Pakistan & Pakistan & 1 & 1 & 2 \\
\hline & Philippines & Philippines & 1 & & 1 \\
\hline \multicolumn{3}{|l|}{ Federal Skilled Worker Total } & 18 & 19 & 37 \\
\hline \multirow[t]{3}{*}{ Investor, entrepreneurs and self-employed } & Iran & Iran & 1 & 1 & 2 \\
\hline & & Philippines & & 1 & 1 \\
\hline & Taiwan & Taiwan & 1 & & 1 \\
\hline \multicolumn{2}{|l|}{ Investor, entrepreneurs and self-employed Total } & & 2 & 2 & 4 \\
\hline Provincial Nominee Program & India & India & & 1 & 1 \\
\hline \multicolumn{4}{|l|}{ Provincial Nominee Program Total } & 1 & 1 \\
\hline \multicolumn{3}{|l|}{ Grand Total } & 28 & 24 & 52 \\
\hline
\end{tabular}

The following table 6 reveals that $75 \%(n=39)$ of the participants passed the English proficiency

test required by the schools and the dental regulatory bodies.

Table 6) English Proficiency Test

\begin{tabular}{llllllll}
$\begin{array}{l}\text { English } \\
\begin{array}{l}\text { Proficiency } \\
\text { test passed }\end{array}\end{array}$ & $25-29$ & $30-34$ & $35-39$ & $40-44$ & $45-49$ & 50 & Total \\
No & & 2 & 2 & 2 & 3 & 4 & 13 \\
Yes & 9 & 16 & 3 & 8 & 2 & 1 & 39 \\
\hline Grand Total & $\mathbf{9}$ & $\mathbf{1 8}$ & $\mathbf{5}$ & $\mathbf{1 0}$ & $\mathbf{5}$ & $\mathbf{5}$ & $\mathbf{5 2}$ \\
\hline
\end{tabular}


Some of the participants in the survey had already written the required exams for licensing. All 52 participants had written the Assessment of Fundamental Knowledge (AFK) at least once and $77 \%(\mathrm{n}=32)$ had passed the exam (Table 7). The registration fee for AFK is currently $\$ 600$. A total of 32 of the 52 participants had taken the Assessment of Clinical Judgement (ACJ) at least once and 32\% ( $\mathrm{n}=17)$ of them had passed (Table 8$)$. The registration fee for ACJ is currently $\$ 1200$. The third exam which is considered the most challenging has a $\$ 5000$ registration fee. Out of the 52 participants, $48 \%(\mathrm{n}=25)$ had taken the Assessment of Clinical Skills (ACS) and only 2\% ( $\mathrm{n}=1)$ had passed (Table 9). These three exams are offered once a year and can be taken up to three times.

Table 7) Age Distribution of the Participants Who Passed the Assessment of Fundamental Knowledge

\begin{tabular}{ll}
\hline Age & passed AFK \\
\hline $\mathbf{2 5 - 2 9}$ & 6 \\
$\mathbf{3 0 - 3 4}$ & 14 \\
$\mathbf{3 5 - 3 9}$ & 5 \\
$\mathbf{4 0 - 4 4}$ & 7 \\
$\mathbf{4 5 - 4 9}$ & 5 \\
over 50 & 3 \\
\hline \multicolumn{2}{|c}{$\mathbf{4 0}$} \\
Grand Total & $\mathbf{( 7 7 \% )}$ \\
\hline
\end{tabular}

Table 8) Age Distribution of the Participant Who passed the Assessment of Clinical Judgment

\begin{tabular}{|c|c|}
\hline Age & Passed ACJ \\
\hline $25-29$ & 1 \\
\hline $30-34$ & 8 \\
\hline $35-39$ & 3 \\
\hline $40-44$ & 2 \\
\hline $45-49$ & 2 \\
\hline over 50 & 1 \\
\hline \multicolumn{2}{|l|}{ Grand } \\
\hline Total & $17(32 \%)$ \\
\hline
\end{tabular}

Table 9) Age Distribution of the participants who passed the Assessment of Clinical Skills

\begin{tabular}{ll}
\hline Age & $\begin{array}{l}\text { passed } \\
\text { ACS } \\
\text { 30-34 }\end{array}$ \\
\hline Grand Total & 1 \\
\hline
\end{tabular}

The international dentists spend a number of years preparing for each exam. As indicated in the following chart (1), the majority of the participants had studied at least one year for each exam but not all of them passed. 
Chart 1) Number of years participants studied for exams

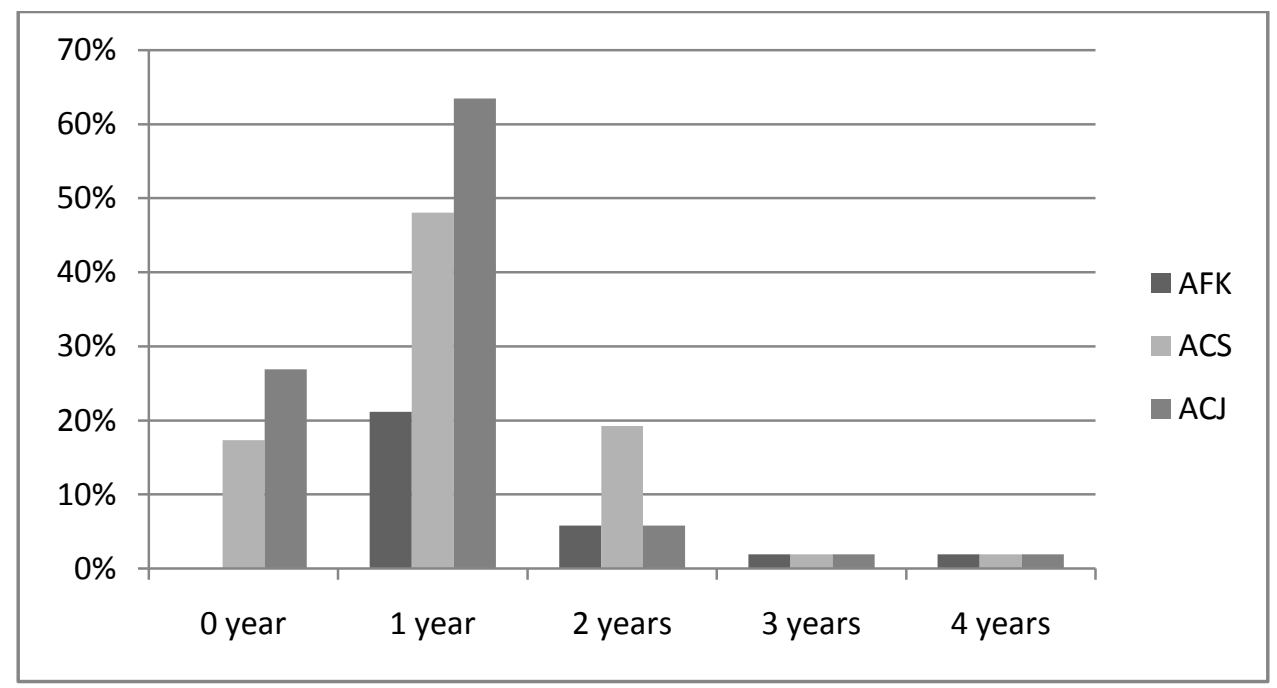

The survey results reveal that $75 \%$ of the dentists who participated had taken private dental training courses to prepare them for exams. Also, as indicated in table $10,31 \%$ of the participants had already spent over $\$ 21,000$. (Table 10)

Table 10) Count of Dentists Who Attended Dental Training Classes and the Costs Associated with Preparing for Exams.

\begin{tabular}{lccc}
$\begin{array}{l}\text { Count of dentists } \\
\text { attended dental } \\
\text { Training Classes }\end{array}$ & & & \\
$\begin{array}{l}\text { Costs during training } \\
\text { and preparation }\end{array}$ & No & Yes & $\begin{array}{l}\text { Grand } \\
\text { Total }\end{array}$ \\
\hline $\begin{array}{l}\text { under } \$ 5000 \\
\$ 6000-\$ 10000\end{array}$ & 7 & 1 & $8(15 \%)$ \\
\hline $11000-\$ 20000$ & 3 & 8 & $11(21 \%)$ \\
over $\$ 21000$ & 2 & 15 & $17(33 \%)$ \\
\hline Grand Total & 1 & 15 & $16(31 \%)$ \\
\hline & 13 & 39 & $\mathbf{5 2}$
\end{tabular}


As indicated in table 11 the participants used different sources of income and sometimes more than one source in order to manage their living expenses during their study period. Approximately half $(48 \%, \mathrm{n}=25)$ of the participants used their savings plus other sources. In addition, 44\% $(n=23)$ of the participants declared their spouse's income was used to pay for their expenses, $12 \%(n=6)$ of them worked part time and $13 \%(n=7)$ worked full time. Only $4 \%(n=2)$ had used government social assistance.

Table 11) Source of income to pay for living expenses

\begin{tabular}{|c|c|c|c|c|c|c|}
\hline $\begin{array}{l}\text { Living } \\
\text { expenses } \\
\text { paid by }\end{array}$ & Loan & $\begin{array}{l}\text { Spouse } \\
\text { Income }\end{array}$ & Savings & $\begin{array}{l}\text { Government } \\
\text { Social } \\
\text { Assistance }\end{array}$ & $\begin{array}{l}\text { Work } \\
\text { part } \\
\text { time }\end{array}$ & $\begin{array}{l}\text { Work Full } \\
\text { Time }\end{array}$ \\
\hline$F$ & 7 & 15 & 14 & 1 & 4 & 3 \\
\hline$M$ & 9 & 8 & 11 & 1 & 2 & 4 \\
\hline Grand Total & 16 & 23 & 25 & 2 & 6 & 7 \\
\hline (\%) & $31 \%$ & $44 \%$ & $48 \%$ & $4 \%$ & $12 \%$ & $13 \%$ \\
\hline
\end{tabular}

The participants in the study obtained information about dental licensing in Canada through one or more of the following three resources. Slightly more than a third $(37 \%, n=19)$ searched online; $6 \%$ accessed information from Citizenship and Immigration Canada's website; $13 \%$ used the Royal Collage of Dental Surgeons website and 17\% simply used a general search engine. A majority $(60 \%, \mathrm{n}=31)$ of the international dentists, obtained information through friends and colleagues and only $2 \%(\mathrm{n}=1)$ obtained licensing information through a Newcomer Centre or Settlement Service agency (Table 12). 
Table 12) Resources used to obtain information on dental licensing

$\begin{array}{|llll|} & & \begin{array}{l}\text { Through } \\ \text { Friends } \\ \text { and } \\ \text { Colleagues }\end{array} & \begin{array}{l}\text { Newcomer } \\ \text { Centre/ } \\ \text { Settlement } \\ \text { Services/ }\end{array} \\ \text { YMCA }\end{array}$

Table 13 illustrates the responses of participants to a number of dichotomized questions. When asked about access to information, $60 \%(n=31)$ of the participants responded that they did not have difficulty obtaining information regarding licensing in Canada (question a) and 56\% (n=29) found the staff helpful when seeking information regarding licensing (question b). A majority, $73 \%(n=38)$ of the participants had knowledge of the dental licensing process in Canada prior to their arrival (question c) and 47\% (n=40) of them responded that they would have immigrated to Canada despite being aware of the difficulties of the current licensing process (question d). In addition, $73 \%(\mathrm{n}=38)$ of the participants expressed their interest in moving to another city if a faster licensing process was offered (question e).

Table 13) a. Difficulty obtaining information; b. Staff helpful when getting information; c. Aware of dental licensing in Canada before arrival; d. Choice of immigrating to Canada with prior knowledge about licensing; e. Moving to another city for a faster licensing process.

\begin{tabular}{|ll|}
\hline & $\begin{array}{l}\text { Did you have } \\
\text { difficulty } \\
\text { obtaining } \\
\text { information }\end{array}$ \\
\hline a. & $31(60 \%)$ \\
\hline No & $21(40 \%)$ \\
\hline Yes & $\mathbf{5 2}$ \\
\hline Grand Total &
\end{tabular}

\begin{tabular}{|ll|} 
& $\begin{array}{l}\text { Were staff } \\
\text { helpful when } \\
\text { getting } \\
\text { information }\end{array}$ \\
b. & $3(6 \%)$ \\
\hline n/a & $20(38 \%)$ \\
No & $29(56 \%)$ \\
Yes & $\mathbf{5 2}$ \\
\hline Grand Total & \\
\hline
\end{tabular}




\begin{tabular}{|ll}
\hline c. & $\begin{array}{l}\text { Were aware } \\
\text { of dental } \\
\text { licensing in } \\
\text { Canada before } \\
\text { landing }\end{array}$ \\
\hline No & $14(27 \%)$ \\
Yes & $38(73 \%)$ \\
\hline Grand Total & $\mathbf{5 2}$ \\
\hline
\end{tabular}

\begin{tabular}{|ll}
\hline & $\begin{array}{l}\text { Would have } \\
\text { immigrated to } \\
\text { Canada with } \\
\text { prior knowledge } \\
\text { of licensing }\end{array}$ \\
\hline d. & $12(23 \%)$ \\
\hline No & $40(77 \%)$ \\
Yes & $\mathbf{5 2}$ \\
\hline Grand Total & \\
\hline
\end{tabular}

\begin{tabular}{|c|c|}
\hline e. & $\begin{array}{l}\text { Going to other } \\
\text { Canadian cities if } \\
\text { faster process } \\
\text { offered }\end{array}$ \\
\hline No & $14(27 \%)$ \\
\hline Yes & $38(73 \%)$ \\
\hline Grand Total & 52 \\
\hline
\end{tabular}

Out of the total of 52 participants, 23 of had been accepted in the Qualifying program at the University of Toronto and upon completion of the program could practice dentistry. The remaining 29 participants were still in the process of completing exams in order to meet the minimum requirements for the two pathways mentioned in Chapter 4 with no guarantee of the outcome. Comparing the two groups revealed the following findings:

1) Age: All of the participants in the program were under 45 years of age; $48 \%$ of the participants in the program were 30-34 years of age. 
Chart 2) and Table 14) Age comparison between participants accepted into the Qualifying Program and those not in the program.

Table 14

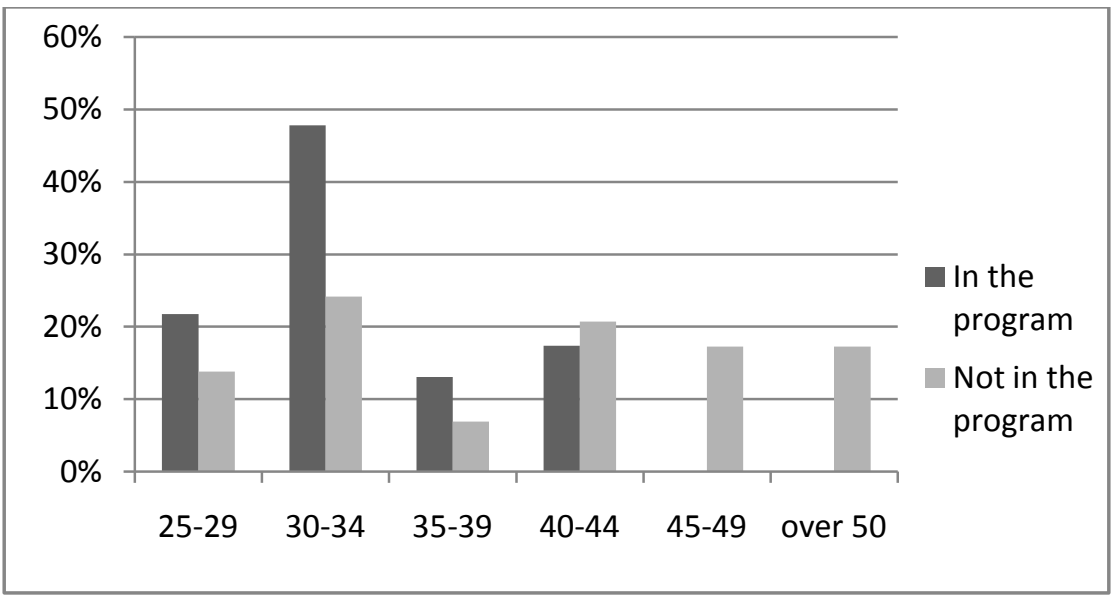

\begin{tabular}{|lll|}
\hline & & Not in \\
Gender & Program & Program \\
$25-29$ & 5 & 4 \\
$30-34$ & 11 & 7 \\
$35-39$ & 3 & 2 \\
$40-44$ & 4 & 6 \\
$45-49$ & 0 & 5 \\
over 50 & 0 & 5 \\
\hline
\end{tabular}

2) Years of study for the AFK: A comparison of the average number of years the participants had studied for the Assessment of Fundamental Knowledge which all participants had taken at least 1 time, did not reveal any significant difference between the two groups. The average number of years studied for AFK was 1.5 for dentists in the program and 1.3 for those not in the program.

3) Those who were aware of licensing process: The results show that $87 \%$ of the participants in the qualifying program knew of the licensing process in Canada prior to immigration as opposed to $62 \%$ of those not in the program.

Chart 3) Percentage of participants who were aware of the licensing process in Canada prior to immigration

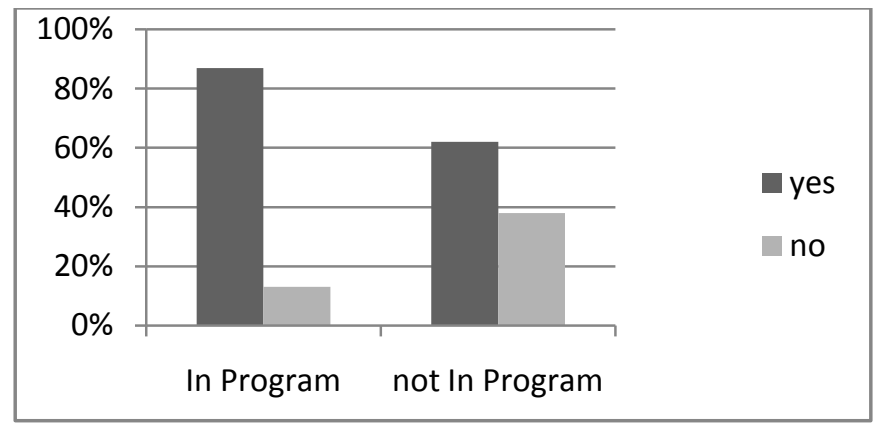


4) Immigration to Canada: $91 \%$ of the participants who are in the program responded positively to whether or not they would have immigrated to Canada if they had the current knowledge of the difficulties of the licensing system as opposed to 66\% of those not in the program.

Chart 4) Percentage of participants who would have been willing to immigrate to Canada based on their current knowledge of difficulties in Licensing

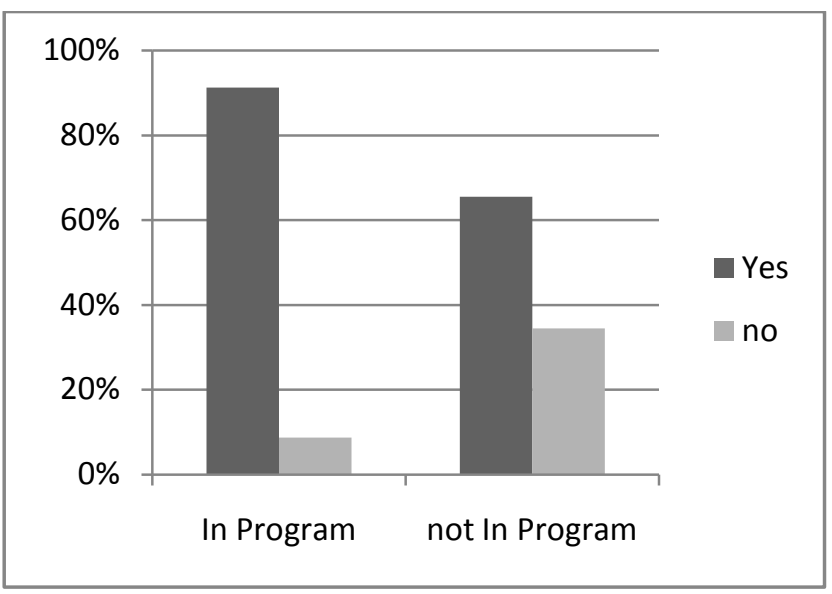

In response to the open-ended question which asked the participants to state what had been the most challenging part of the process of getting their Canadian dental accreditation, they identified the following issues:

1) Working in jobs outside their profession was very difficult.

2) It was challenging to be able to pay for the expenses related to licensing as well as support their family.

3) Women expressed the difficulty of not having child care and not having enough time to study.

4) There was no financial support, bridging program or practice setting to prepare for written and clinical exams or any government assistance offered. 
5) The Assessment of Clinical Skilled exam was mentioned by many as the most challenging one and some believed the grading of the exam was based on the examiners' subjective judgment. Also, the registration fee and the expense of the equipment they had purchased to complete the exam were burdens for these dentists. Out of 25 participants who attempted this exam, only 1 had passed.

6) The score of $75 \%$ for the Assessment of Fundamental Knowledge which was the minimum requirement for the next exams and dentistry schools was not competitive. Internationally trained dentists who scored over $90 \%$ were also not guaranteed access to licensing.

Some of the participants made the following comments:

A female from Pakistan who had been in Canada for 3.5 years, had attempted all three exams two times, but only passed the AFK exam and was accepted into the qualifying program explained (the qualifying program at University of Toronto only requires an AFK exam score and not the other two):

"There is a very high volume of foreign trained dentists applying for this dental accreditation process but there are only a specific number of seats and students chosen for the qualifying programs so the rest have to continue to strive till they get in."

A male from India who had been in Canada for 2 years and had attempted all three exams failing only the ACS exam explained:

"The most challenging part of the process for me is to support my family and maintain a balance between family and profession." 
A female from India who had been in Canada for only 1 year and attempted all three exams, but only passed the AFK exam and was accepted into the qualifying program stated:

"The Canadian government should offer a bridging program at no cost/ subsidised to enable us to join the workforce. We end up spending all our savings, shed blood and tears before we get into mainstream dentistry, if we do."

A female from China who had been in Canada 6 years and had attempted all three exams and not passed the ACS exam wrote:

"I believe money and managing time to do work and practicing for exams are the most difficult and challenging part of this process."

A participant from Iran who had been in Canada for 1.5 years and had successfully written the AFK exam wrote:

"I came here as a skilled worker with more than 15 years of experience but was without a matching job for 1.5 years- to pass the exams, and spent more than $\$ 30000$ just for registering and preparation for the exam. If I fail I will get not only be broke as I have been without income, I will get depressed too which will affect my family and children." 


\section{Chapter 7}

\section{Discussion}

The findings presented in Chapter 6 provide insight into the process of licensing for internationally trained dentists and the challenges they face during the process of accreditation. Most $(71 \%)$ of these participants had immigrated to Canada through the FSW program and the rest could have qualified under the FSW program, which demonstrates their high level of skills, education and language proficiency. Therefore, looking at their experiences during the process of licensing helps to understand and measure the outcome of making education a major determinant of immigration selection. The assessment exams are used as a tool in measuring the worth of knowledge and skills of these professionals. As Newson (2013) explains, the regulatory bodies have difficulty understanding the training systems of other countries. Since more immigrants are arriving to Canada from non- English speaking third world countries as this research confirms, the lack of understanding or acceptance of the standards in these countries delays the professional accreditation process and licensing.

The findings of this study indicate that internationally trained dentists face a number of difficulties when going through the licensing process. While two thirds of the participants of the survey had achieved the required score on the Assessment of Fundamental Knowledge exam, which is a minimum requirement of the qualifying dentistry programs, many of them would not be able to enter a program because limited seats are available. Many of the participants claimed that their marks had to be very competitive in addition to meeting other requirements. Based on an e-mail communication in December 2013 with the eight schools that offer the qualifying 
program, it was determined that a total of approximately 70 international dentists are accepted into dentistry programs each year.

Furthermore, the survey data indicated that 3 out of 4 of the participants had already achieved the required English proficiency score. The presentation of one's skills and abilities is vital for professional dentists because they need to show their technical knowledge, as well as communicate with their patients effectively. The findings of this study reveal that in the case of this group of internationally trained dentists who are preparing for licensing, proficiency in the English language is not a major barrier. Even though CIC (2010) has considered language as the second most important determinant of employability of immigrants, having strong language skills does not increase the chances of success of internationally trained dentists. Many of the internationally trained dentists who had not succeeded in getting a license had passed English language proficiency tests.

Preparing for the three exams has been identified as one of the biggest challenges these international dentists have faced. The costs of these exams mentioned in the previous chapter, as well as the supplies and preparation classes impose a great financial burden on these individuals and their families. As Newson (2013) explains, the hundreds or even thousands of dollars spent on credential recognition can have long term implications for these immigrants. The fact that $31 \%$ of the participants of this study have spent over $\$ 21,000$ on licensing related expenses alone and many of them are still continuing in the process and have not succeeded illustrates the financial pressures they endure. For those who relied on their spouses financially (44\%), the process of accreditation can create additional stress and feelings of obligation. In addition, close to half of the participants who claimed to have used their savings to pay for their living expenses face the additional pressure of losing their life savings to pay for the costs of a process that does 
not guarantee success. Working in occupations unrelated to dentistry, often at survival jobs, not only creates additional stress, it also reduces their study time. It is also important to note that despite the fact that these internationally trained dentists are in financial need and rely on loans, savings, spousal income or employment, $96 \%$ of them have not used social assistance during the course of their preparation and studies.

One of the issues mentioned in the literature and reports on accreditation focuses on the difficulties internationally trained professionals face in obtaining information about the accreditation process in Canada. Based on the results of this study, $60 \%$ of internationally trained dentists did not face this difficulty and $56 \%$ found staff of the Royal College of Dental Surgeons helpful when seeking information. This could be due to the fact that the Royal College of Dental Surgeons of Ontario and the National Dental Examining Board are the only two bodies involved in Ontario which reduces the complication of the process. Applying to different schools and understanding each of their requirements can be confusing but not a major obstacle for these dentists. What is significant is the fact that only $2 \%$ of the participants had approached a settlement organization or newcomer centre to obtain information about licensing. The rest had either obtained information online (38\%) or relied on friends and colleagues $(60 \%)$.

While government funds the settlement sector, the participants of this study have not benefited from services for immigrants. One reason for not seeking information from the settlement sector can be the fact that $73 \%$ of the participants were already aware of the licensing process prior to arriving in Canada. In addition, the government's lack of involvement in the process of dental accreditation can be the reason for the lack of interest the internationally dentists have shown in approaching the settlement sector. There are no bridging programs offered by a government institution or a licensed body. As indicated in chapter 6, 3 out of 4 of 
the study participants had taken training courses in private, non- licensed institution to prepare for the exams. For a very high fee, these classes provide notes, interview tips, sample questions and practice setting for internationally trained dentists. They are taught by those who have already gone through the process. The fact that these institutions operate without a license and are free to charge the dentists any amount they want makes the situation of these internationally trained dentists very vulnerable.

Although, the licensing process is very challenging, competitive, and expensive and the rate of success is low, almost half of the internationally trained dentists who participated in this study claim that living in Canada outweighs success in licensing. This positive response can also be due to the fact that these internationally trained dentists are either already in the program or have hopes of succeeding. The study was not able to include internationally trained dentists who had given up or had failed the process of licensing. Certainly, success in entering a qualifying program made the internationally trained dentists feelings toward Canada more positive. Significantly, $91 \%$ of those in the program that led to licensing claimed that they would have immigrated to Canada whether or not they were aware of the licensing process as opposed to $66 \%$ of those not in the program.

As the data demonstrates, the younger immigrants have been more successful in entering the qualifying program. All of the participants already in the program were under the age of 45 which shows the advantages of being younger in the process of integration. While the dental professionals do not suggest that the decision made by the licensing bodies or universities is influenced by the age of the applicants, the result of this study shows that younger immigrants have a better chance of overcoming the difficulties of licensing. These outcomes suggest that the 
emphasis of the Canadian government in the Economic Action Plan (2012) on bringing younger immigrants because they integrate faster is justified.

The consequences of not getting a license in Canada after enduring the stress of the cost and time spent remain high for internationally trained dentists. There is no alternative pathway or options for these dentists other than pursing another occupation. Although it is not clear how many internationally trained dentists are trying to get a license in Canada, based on the number of participants writing the exams mentioned in the NDEB website, the number of internationally trained dentists going through the process is high. For example, 1187 applicants wrote the AFK exam in 2013. This number compared with the number of seats available in qualifying programs or Equivalency Process is high.

Looking at the process of accreditation of internationally trained dentists and examining the challenges these immigrants face, underlines the huge risk they take when immigrating to Canada. It is evident that the employment outcomes of this group of professionals are mainly determined by whether they succeed or not in getting a license. This study reveals that close to two thirds of the participants of the study had landed in Canada through the FSW program. While it is acceptable that Canada, similar to most countries in the world, requires licensing for internationally trained dentists, it is up to the immigrant to deal with the challenges and barriers of the process of licensing. Considering that the immigrants have limited resources, this puts them at a great disadvantage (Remennick, 2012). This observation is indicative of the disconnect between the goals of Canada's immigration system and the accreditation process immigrants must complete. Perhaps, the recent changes to the FSW program which excludes dentists are justified considering the number of international dentists currently seeking licensing. 
As discussed in earlier chapters, the Canadian government's recent occupation list which defines whose application will be considered does not include dentists. Therefore, they are no longer eligible to apply through the Federal Skilled Worker program. However, there is still a large group of internationally trained dentists struggling to be licensed. As Sumption (2013) has recommended, by offering more innovative approaches such as lowering the costs of registration, offering online training tools and providing low cost student loans, the government can help professionals complete the process of accreditation. For example, the Assessment of Clinical Skills exam has a $\$ 5000$ registration fee and the participants are required to buy all supplies and equipment needed for the exam to be performed on a patient. The rate of success in this exam is very low. As indicated by the internationally trained dentists who took the survey, the examiners judgment is subjective and there is no clear protocol on what is accepted. Failing this exam, which is often the case, results in losing a large amount of money and is also a waste of time and effort for the internationally trained dentists.

The Canadian FCR process is "all-or-nothing", they either get accreditation or are unable to practice dentistry. In fact, it does not offer the international dentists partial or conditional registration that would allow them to perform some related dental activity while going through the accreditation process. As one of the participants of the survey expressed, having the opportunity to work in a dental setting, even as an assistant, would have helped him understand the Canadian dental system. The underutilization of international dentists' skills is a poor outcome; the Canadian immigration selection process fails to get a high return on the human capital of many of the highly skilled immigrants. In addition, the growing pool of licensed dentists indicates that Canada does not need these federal skilled workers who had been

\footnotetext{
${ }^{6}$ Sumption (2013) explains that in several countries, policy makers have pushed regulatory bodies to avoid an "allor-nothing" approach to certifying foreign professional.
} 
admitted to meet the Canadian labour market needs (Balckwell, 2013). Perhaps, the changes to the FSW program which excludes dentists are justified considering the number of dentists in Canada. These changes in policy can prevent flooding the market by having too many dentists practicing in Canada. In fact, Dr. Robert Sutherland (President, Canadian Dental Association) at the Human Resources, Skills and Social Development and the Status of Persons with Disabilities Committee (2012) stated that there is no shortage of dentists. According to Sutherland (2012) "Canada is on a par with other OECD countries in terms of the dentist to population ratio". He explained that based on the results of Statistics Canada's health measures survey, $75 \%$ of Canadians saw a dentist at least once a year, and $86 \%$ have seen a dentist in the past two years (Sutherland, 2012).

Sutherland (2012) also revealed that the existing issue in the dental field is the distribution of Canadian dentists. While $21 \%$ of the Canadian population resides in rural areas, $11 \%$ of dentists live in rural areas (Sutherland, 2012). To resolve this issue and prevent flooding the market for bigger cities in Canada, the government can offer either faster ways of licensing or financial grants during the accreditation process to those internationally trained dentists who would be willing to practice in a rural area for a number of years. The results of this study revealed that majority of the participants (73\%) would be willing to relocate to another city (other than Toronto, Montreal, Vancouver) if a faster licensing process was offered.

The fact that many internationally trained dentist are competing to get a license to practice suggest the high level of human capital currently present in cities such as GTA. Whether or not their skills will be utilized remains unanswered since there are not enough spots in university dentistry programs or direct licensing available to allow these dentists to join the labour market and practice in their own field. Perhaps the government should allow 
internationally trained dentists to pursue career options within the dental field using the exam results they have already acquired. Knowing that not getting a license does not mean their time and efforts will be wasted could reduce the stress of attempting to complete the accreditation process.

\section{Limitations of the Study}

One of the limitations of this study among many was the small sample. In addition, the study did not include internationally trained dentists who had given up studying and those who were already licensed. It was also not clear how many internationally trained dentists who were seeking licensing are currently living in Canada. Therefore, the data could not be tested statistically against a larger population. Due to the lack of access to internationally trained dentists in other Canadian provinces going through the accreditation process, their experiences were not reflected in this research. 


\section{Appendix 1}

Eligible occupations

must have one year of continuous, full-time (or an equal amount of part-time) paid work experience, in at least one of these occupations within the last ten years:

- 0211 Engineering managers

- 1112 Financial and investment analysts

- 2113 Geoscientists and oceanographers

- 2131 Civil engineers

- 2132 Mechanical engineers

- 2134 Chemical engineers

- 2143 Mining engineers

- 2145 Petroleum engineers

- 2144 Geological engineers

- 2146 Aerospace engineers

- 2147 Computer engineers (except software engineers/designers)

- 2154 Land surveyors

- 2174 Computer programmers and interactive media developers

- 2243 Industrial instrument technicians and mechanics

- 2263 Inspectors in public and environmental health and occupational health and safety

- 3141 Audiologists and speech-language pathologists

- 3142 Physiotherapists

- 3143 Occupational Therapists

- 3211 Medical laboratory technologists (Cap reached)

- 3212 Medical laboratory technicians and pathologists' assistants

- 3214 Respiratory therapists, clinical perfusionists and cardiopulmonary technologists

- 3215 Medical Radiation Technologists

- 3216 Medical Sonographers

- 3217 Cardiology technologists and electrophysiological diagnostic technologists

These occupations are either:

Skill Type 0 (management occupations) or

Skill Level A (professional occupations) or

Skill Level B (technical occupations and skilled trades)

on the Canadian National Occupational Classification list.

Source : Citizenship and Immigration Canada (2014). Specific Eligibility Criteria - Federal skilled workers. http://www.cic.gc.ca/english/immigrate/skilled/apply-who-instructions.asp 


\section{Appendix 2}

The diagram below illustrates the integrated pathways to certification as a dentist in Canada.

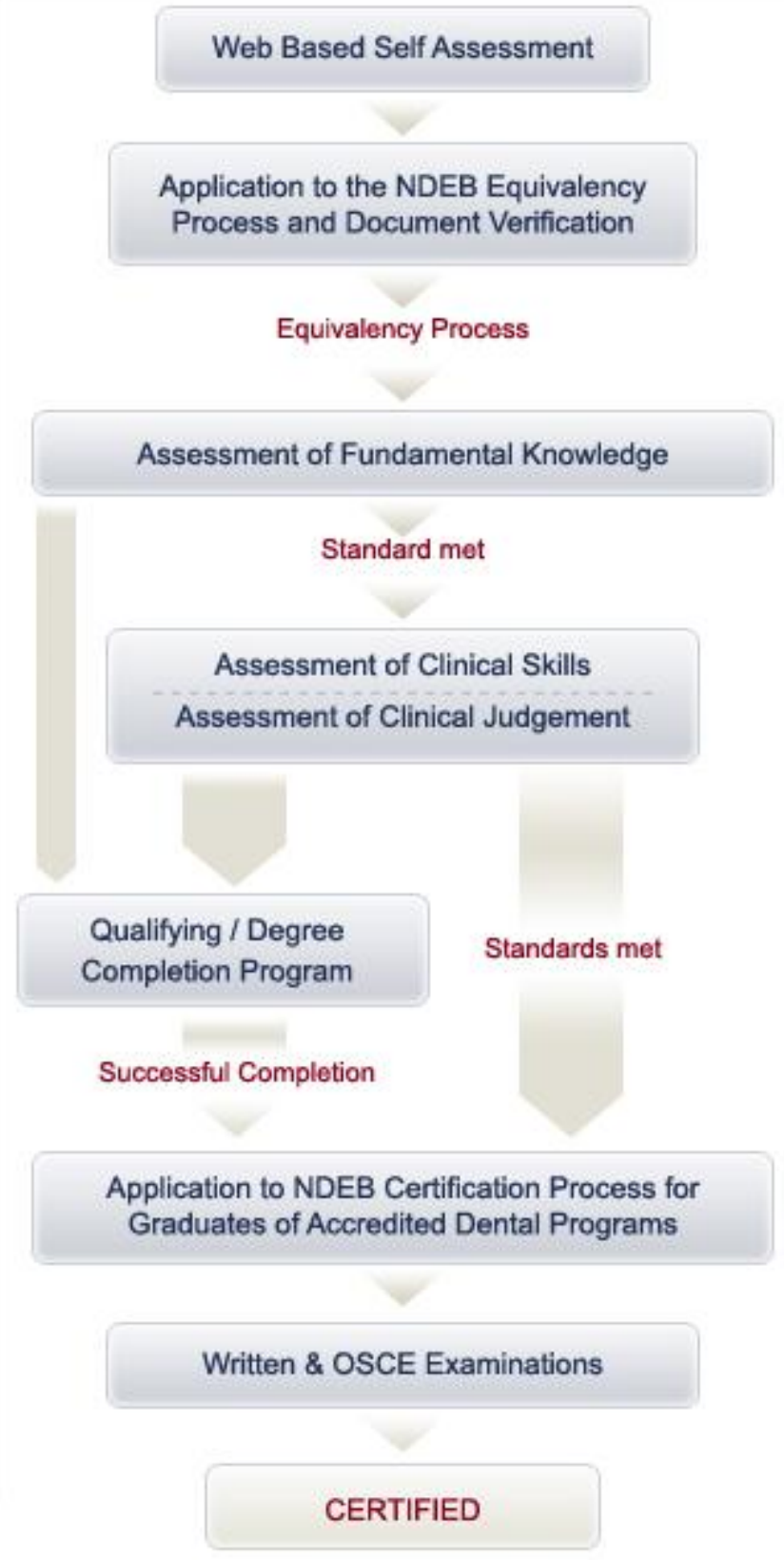




\section{Appendix 3}

Qualifying or Degree Completion Program Contacts

BRITISH COLUMBIA

Mrs. Viki Koulouris, Manager, Admissions

Faculty of Dentistry

University of British Columbia

296A - 2199 Westbrook Mall

Vancouver, BC V6T 123

Telephone: $604-822-4486$ / fax: $604-822-8279$ /email: fodadms@dentistry.ubc.ca

\section{ALBERTA}

Ms. Melanie Grams, Administrator, Admis sions

Department of Dentistry

University of Alberta

Room \#3028 Dentistry/Pharmacy Ctre (DPC)

Edmonton, $\mathrm{AB}$ T6G 2N8

Telephone: 780-492-1319/ fax: 780-492-7536/email: melanie. grams Qualberta.ca

\section{MANITOBA}

Jean Lyon, IDDP Coordinator

Faculty of Dentistry

University of Manitoba

D113 - 780 Barnatyng Avenue

Winnipeg, MB R3E 0W2

Telephone: 204-977-5611 / fax: 204-789-3912 / email: dean iddpQumanitobaca

\section{ONTARIO}

Internationally Trained Dentists (ITD) Program

Coordinator

Schulich School of Medicine \& Dentistry

University of Western Ontario

Dental Sciences Building, Room 1003

London, ONN6A 5Cl

Telephone: 519-661-2111/ fax: 519-661-3875/e-

mail: itd.prosram@schulich.uwo.ca

Mrs. Margaret Edghill, Faculty Registrar

Faculty of Dentistry

\author{
University of Toronto \\ 124 Edward Street \\ Toronto, ONM5G 1 G6 \\ Telephone: 416-979-4901-1-4374/ fax: 419-979- \\ 4944 / e-mail: admissions.dental@utoronto.ca \\ QUEBEC \\ Ms. Marie-ClaudeLoigngn Admissions and \\ Recruitment Officer \\ Admissions Office \\ McGill University \\ Faculty of Dentistry \\ 3640 University Street, Rm 2/38B \\ Montreal, PQ H3A 0C7 \\ Telephone: 514-398-7203/Fax: 514-398-8900/e- \\ mail: undergrad.dentistry@mcrill.ca \\ M. Claude-Andre, A gente d'evalugtion \\ Service de l'admis sion et du racrutement

\section{Unixersitéde Montréal} \\ Faculté de médecine dentaire m. \\ C.P 6205. Sucs Centre-ville \\ Montréal, PQ H3C 3T5 \\ Telephone: 514-343-7076/Fax: 514-343-5788/e- \\ mail: claude-andre.dupras@umontreal.ca
}

\section{NOVA SCOTIA}

Ms. Nancy Webb, Academic Manager

Faculty of Dentistry

Dalhousie University

5981 University Avemue

Halifax, NS B3H $3 \mathrm{~J} 5$

Telephone: 902-494-2824 / fax: 902-494-2527 / email: n.webb@dalca 


\section{Appendix 4}

1. Gender: Male $\square$ Female $\square$

2. What age group do you fall into?
a) $25-29$
b) $30-34$
c) 35-39
d) $40-44$
e) $45-49$
f) Over 50

3. What is your country of origin?

4. Which one of the Canadian immigration programs did you apply for?
a) Federal Skilled Worker
b) Investor, entrepreneurs and self-employed
c) Refugee
d) Family Sponsorship
e) Provincial Nominee Program

5. How long have you lived in Canada?

6. Which country did you first obtain your dental degree from?

7. How many years did you practice as a dentist before coming to Canada?
a) 1-2years
b) 3-5years
c) 6-10years
d) over 11 years

8. Did you pass the English Proficiency test required for Dental licensing?

a) Yesb)No

9. How many years did you study for the following tests? Please check the box.

a) Assessment of Fundamental Knowledge Exam (AFK):

Less than 1year $\square, 2$ years $\square, 3$ years $\square$, over 4year's $\square$

b) Assessment of Clinical Skills (ACS):

Less than 1year $\square, 2$ years $\square, 3$ years $\square$, over 4year's $\square$

c) Assessment of Clinical Judgments (ACJ):

Less than 1year $\square$, 2years $\square, 3$ years $\square$, over 4year's $\square$

10. How many times have you taken the following tests? Please check the box.

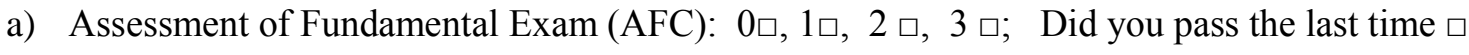

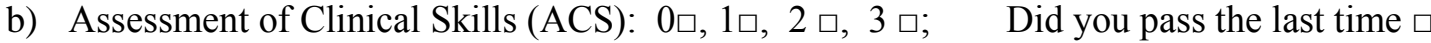

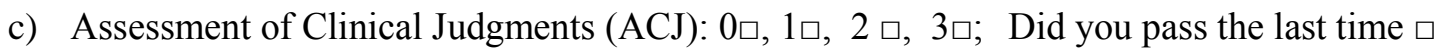

11. Did you attend a Training Centre to prepare for the tests?
a) Yesb) No

12. How much money have you spent (approximately) on fees for English and dental assessment tests, training courses, and books prior to getting into the program?
a) Under $\$ 5000$
b) $\$ 6000$ to $\$ 10000$
c) $\$ 11000$ to $\$ 20000$
d) Over 21000

13. How long (from the time you started studying for the tests including Language proficiency test) did it take you to get accepted into the Qualifying/ degree completion Program? [if relevant]
a) Under 2 year
b) 3-4 years, c) 5-6 years, Over 7years

14. During your study period, including your preparation for the exam, how did you manage to pay for your living expenses? Please check all that apply to you. 

a) Loan
b) Spouse/ partner income
c) Saving
d) Government social assistance
e) Work : please check Part time $\square$ or Full time $\square$

15. How did you find out about the accreditation program (Dental Licensing Program) first?

a) Online Search- please select one

i. $\quad$ Citizenship and Immigration Canada (CIC)

ii. Royal Collage of Dental Surgeons

iii. Human Resources Development Canada

iv. General Search Engine/ Others

b) Through Friends and Colleagues

c) Newcomer Centre/ Settlement Services/YMCA

d) Other, please specify :

16. Did you have difficulty obtaining information about getting a dental license in Canada?

a) Yesb) No

17. Did you find the staff/ officials you approached to gather information about the recognition of your dental degree and/or to evaluate your degree helpful?

a) Yesb) No

18. Were you aware of the dental licensing process in Canada before landing here as an immigrant? a) Yesb) No

19. Would you have immigrated to Canada if you had known about the accreditation/ licensing process for foreign Dentists in Canada, prior to moving to Canada?

a) Yesb) No

20. Would you have considered going to other Canadian cities (other than Toronto, Montreal, Vancouver) if a faster licensing process was offered?
a) Yes
b) No

\section{OPTIONAL}

21. What has been the most challenging part of the process of getting your Canadian dental accreditation for practicing in Canada? Please explain. 


\section{References}

Alan G Green, \& David Green. (2004). The goals of Canada's Immigration Policy: A Historical Perspective. Canadian Journal of Urban Research, 13(1), 102.

Alboim, N., \& Cohl, K. (2012). Shaping the future: Canada's rapidly changing immigration policies. Toronto, ON: Maytree.

Alboim, N., Finnie, R., \& Meng, R., \& Institute for Research on Public Policy. (2005). The discounting of immigrants' skills in Canada: Evidence and policy recommendations

Alboim, N., McIsaac, E., \& Institute for Research on Public Policy. (2007). Making the connections: Ottawa's role in immigrant employment

Association of Canadian Faculties of Dentistry (2014). Graduates of Accredited Dental Programs in the USA, Australia, New Zealand or Ireland. Retrieved from http://acfd.ca/licensure/information-forgraduate-of-accredited-programs-in-the-usa/

Beach, Charles. Green, Alan G. Worswick, Christopher. (2006). Impacts of the point system and immigration policy leverson skill characteristics of Canadian immigrants Queen's Economics Department.

Benhabib, J. J., \& Spiegel, M. M. (1994). The role of human capital in economic development: Evidence from aggregate cross-country data. Journal of Monetary Economics, 34(2), 143-173. doi:10.1016/03043932(94)90047-7.

Blackwell, Tom. (2013) Too many dentists means tough times for them, good deals for customers. Retrieved from thttp://globalnews.ca/news/429450/too-many-dentists-means-tough-times-for-them-gooddeals-for-customers-report/

Blaug, M. (1976). The empirical status of human capital theory: A slightly jaundiced survey. Journal of Economic Literature, 14(3), 827-855.

Boyd, M., \& Thomas, D. (2001). Match or mismatch? the employment of immigrant engineers in canada's labor force. Population Research and Policy Review, 20(1), 107-133.

doi:10.1023/A:1010625515456

Canadian Dental Association. (2014). General certification and licensure. Retrieved form http://www.cda-adc.ca/en/becoming/becoming/certification/general.asp

Canadian Network of National Associations of Regulators. (2014). FAQ. Retrieved from http://www.cnnar.ca/en/index.html

Chiswick, B. R., \& Miller, P. W. (2009). The international transferability of immigrants' human capital. Economics of Education Review, 28(2), 162-169. doi:10.1016/j.econedurev.2008.07.002

Citizenship and Immigration Canada. (2008). Backgrounder - Citizenship and Immigration Canada enhanced language training initiative. Retrieved form http://www.cic.gc.ca/english/department/media/backgrounders/2004/2004-05-07.asp

Citizenship and Immigration Canada. (2010). Evaluation of the Federal Skilled Worker program. Retrieved from http://www.cic.gc.ca/english/resources/evaluation/fswp/section5.asp 
Citizenship and Immigration Canada. (2011). ARCHIVED - Strengthening Canada's Economy Government of Canada Progress Report 2011 on Foreign Credential Recognition. Retrieved from http://www.cic.gc.ca/english/resources/publications/fcro/progress-report2011.asp

Citizenship and Immigration Canada. (2013). Six selection factors - Federal skilled workers. Retrieved from http://www.cic.gc.ca/english/immigrate/skilled/apply-factors.asp

Citizenship and Immigration Canada. (2013b). Backgrounder - Information for Applicants to the New Federal Skilled Worker Program. Retrieved from http://www.cic.gc.ca/english/department/media/backgrounders/2013/2013-04-18.asp\#educ

Citizenship and Immigration Canada. (2013d). Evaluation of the Foreign Credentials Referral Office (FCRO). Retrieved from http://www.cic.gc.ca/english/resources/evaluation/fcro.asp

Citizenship and Immigration Canada. (2013c). Foreign Credentials Referral Office. Retrieved from http://www.cic.gc.ca/english/department/fcro/index.asp

Citizenship and Immigration Canada. (2013a). News Release - Canada's new and improved Federal Skilled Worker Program opening to applicants. Retrieved from http://www.cic.gc.ca/english/DEPARTMENT/media/releases/2013/2013-05-03.asp

Coleman, J. S. (1988). Social capital in the creation of human capital. American Journal of Sociology, 94(S1), S95-S120. doi:10.1086/228943

Commission on Dental Accreditation of Canada (2013). International Professionals. Retrieved from http://www.cda-adc.ca/cdacweb/en/international_professionals/

Council of Ministers of Education, Canada (2014). About the center. Retrieved from http://www.cicic.ca/fr/431/about-the-centre.canada

Dental Simulation Training Centre (2014). Courses. Retrieved from http://www.dstcdental.com/index.php/courses

Dhillon- Penner, N. \& Schwartz, B. D., Natasha. (2009). Effective foreign credential recognition legislation: Give it some teeth. 9 Asper Rev. Int'l Bus. \& Trade L. 1.

Economic action plan 2012 :A fast and flexible immigration System: Jobs, growth and long-term prosperity. (2012).Citizenship and Immigration Canada.

Employment and Social Development Canada (2013a). Credential Recognition. Retrieved from http://www.esdc.gc.ca/eng/jobs/credential recognition/index.shtml?utm source=PanCanadian+Framework\&utm medium=Link\&utm campaign=Action Plan Skills Fall 2013

Employment and Social Development Canada (2013b). Summative Evaluation : Foreign Credential Recognition Program, April 2010. Retrieved from http://www.esdc.gc.ca/eng/publications/evaluations/skills_and_employment/2010/april.shtml

Ferrer, A., Picot, G., \& Riddell, W. C. (2012). New directions in immigration policy: Canada's evolving approach to immigration selection. Canadian Labour Market and Skills Researcher Network, 107

George, U., \& Chaze, F. (2012). Credential assessment of internationally trained professionals: How effective is the process for the purpose of securing employment? Journal of Immigrant \& Refugee Studies, 10(1), 124-130. doi:10.1080/15562948.2012.646529 
Girard, E. R., \& Bauder, H. (2007). Assimilation and exclusion of foreign trained engineers in canada: Inside a professional regulatory organization. Antipode, 39(1), 35-35. doi:10.1111/j.1467-

8330.2007.00505.x

Grubel, H. (August 2013). Canada's immigrant selection policies: Recent record, marginal changes, needed reforms. ().Studies in Immigration Policy: Fraser Institute.

Hawthorne, L. (2006). Labour market outcomes for migrant professionals: Canada and Australia compared : Executive summary Canada. Citizenship and Immigration Canada;.

Hawthorne, L. (2007). Foreign credential recognition: Reconnaissance des titres de competence acquis a l'etranger Association for Canadian Studies.

Houle, René \& Yssaad, Lahouaria. (2010). Recognition of newcomers' foreign credentials and work experience. Perspectives on Labour and Income, 22(4), 18.

Human Resources and Skills Development Canada. (2007). Formative evaluation of the foreign credential recognition program. Retrived form

http://publications.gc.ca/collections/collection_2008/hrsdc-rhdsc/HS28-79-2007E.pdf

Ikura, J. (2007). Foreign credential recognition and human resources and social development canada. Canadian Issues, 17.

Imai, S. Stacey, D., \& Warman,C. (2011). From engineer to taxi driver? occupational skills and the economic outcomes of immigrants. Department of Economics: Queen's University.

King, K. M., \& Martin Prosperity Institute. (2009). The geography of immigration in canada: Settlement, education, labour activity and occupation profiles

McDonald, James Ted; Warman, Casey; Worswick, Christopher (2011) : Immigrant selection systems and occupational outcomes of international medical graduates in Canada and the United States, Queen's Economics Department Working Paper, No. 1285

National Dental Examining Board of Canada. (2012).Overview. Retrieved from http://www.ndeb.ca/nonaccredited

National Dental Examining Board of Canada. (2014).Summary of historical pass rates for the ndeb equivalency process. Retrieved from http://www.ndeb.ca/nonaccredited/past-assessment-results

Newson, M. (2013). Foreign qualification recognition, labour market barriers and their impact on migrants and their families. (Family, Migration \& Dignity Special Issue).QScience Proceedings.

Ontario Council of Agencies Serving Immigrants (2014). Which professions are regulated in Ontario? Retrieved from http://www.settlement.org/sys/faqs_detail.asp?faq_id=4001108

Papademetriou, D. S., Madeleine. (2011). Rethinking points systems and employer- selected immigration. (Washington, DC).Migration Policy Institute.

Queen's Printer for Ontario, 2014. Fairness Commissioner: Professions and Trades. Retrieved from http://www.fairnesscommissioner.ca/index_en.php?page=professions/index

Reitz, J. G. (2002). Immigration and Canadian nation- building in the transition to knowledge economy. Center for Industrial Relations: University of Toronto. 
Reitz, J. G. (2003). Occupational dimensions of immigrant credential assessment:Trends in professional, managerial and other occupations, 1970-1996 University of Toronto.

Reitz, J. G., \& Institute for Research on Public Policy. (2005). Tapping immigrants' skills: New directions for Canadian immigration policy in the knowledge economy.

Reitz, J. G. (July 2012). Canada: New initiatives and approaches to immigration and nation-building. Paper presented at the "Immigration policy in an era of globalization," sponsored by the SMU tower center for political studies and the federal reserve bank of dallas, and held in dallas TX on may 18-20, 2011.

Remennick, L. (2013). Professional identities in transit: Factors shaping immigrant labour market success. International Migration, 51(1), 152-168. doi:10.1111/j.1468-2435.2011.00733.x

Royal Collage of Dental surgeons of Ontario. (2013).Information for internnationally educated/trained. Retrieved from

http://rcdso.org/BecomeADentistInOntario/InformationforInternationallyEducatedTrained/FeesandCosts

Royal Collage of Dental surgeons of Ontario. (2014). Access to the Dental Profession in Ontario.

Retrieved from

http://www.rcdso.org/BecomeADentistInOntario/InformationforInternationallyEducatedTrained/Accessto theDentalProfessioninOntario

Royal Collage of Dental surgeons of Ontario. (2014). Fees and costs. Retrieved from

http://rcdso.org/BecomeADentistInOntario/InformationforInternationallyEducatedTrained/FeesandCosts

Schwartz, B. D., Natasha. (2009). Effective foreign credential recognition legislation: Give it some teeth. 9 Asper Rev. Int'l Bus. \& Trade L. 1,

Sutherland, Robert (2012, May 7). (President, Canadian Dental Association) at the Human Resources, Skills and Social Development and the Status of Persons with Disabilities Committee Symposium conducted at Human Resources Committee. Retrieved from https://openparliament.ca/committees/human-resources/41-1/36/dr-robert-sutherland-1/only/

Sumption, M. (2013). Tackilng brain waste: Strategies to improve the recognition of immigrants' foreign qualifications. (). Washington, DC: Migration Policy Institute.

The University of Toronto Faculty of Dentistry. (2013). International dentist advanced placement program for foreign-trained dentists: Academic Requirements. Retrieved from http://www.dentistry.utoronto.ca/admissions/international-dentist-advanced-placement-programidapp/academic-requirements

Zietsma, D. (February 2010). Working in regulated occupations.(Catalogue no. 75-001-X)

World Education Services (2014). Welcome to World Education Services. Retrieved from http://www.wes.org/ca/. 